\title{
Sensitivity Analysis of Runoff Model by SWAT to Meteorological Parameters: A Case Study of Kasillian Watershed, Mazandaran, Iran
}

\author{
Mohsen Ghane ${ }^{1}$, Sayed Reza Alvankar ${ }^{1}$, Saeid Eslamian², Mahboubeh Amoushahi-Khouzani ${ }^{3}$, \\ Amir Gandomkar ${ }^{4}$,Elahe Zamani ${ }^{5}$, Maryam Marani-Barzani ${ }^{6}$, Masoud Kazemi ${ }^{7}$, Morteza $^{2}$ \\ Soltani $^{8}$,Shahide Dehghan ${ }^{4}$, Vijay P. Singh ${ }^{9}$, Kaveh Ostad-Ali-Askari ${ }^{10^{*}}$, Majedeh Haeri- \\ Hamedani $^{2}$, Hamid-Reza Shirvani-Dastgerdi ${ }^{10}$, Zahra Majidifar ${ }^{11}$, Nicolas R. Dalezios ${ }^{12}$, \\ Bahareh Soltani ${ }^{2}$ \\ ${ }^{1}$ Civil Engineering Department, South Tehran Branch, Islamic Azad University, Tehran,Iran. \\ ${ }^{2}$ Department of Water Engineering, Isfahan University of Technology, Isfahan, Iran. \\ ${ }^{3}$ Water Engineering Department, Science and Research Branch, Islamic Azad University, Tehran, Iran. \\ ${ }^{4}$ Department of Geography, Najafabad Branch, Islamic Azad University, Najafabad, Iran. \\ ${ }^{5}$ Department of Physiologyand plant improvement,Ardakan University, Ardakan, Yazd, Iran. \\ ${ }^{6}$ Department of Geography, University of Malaya (UM) ,50603 Kuala Lumpur, Malaysia. \\ ${ }^{7}$ Civil Engineering Department, Najafabad Branch,Islamic Azad University, Najafabad Iran. \\ ${ }^{8}$ Department of Artichetctural Engineering, Shahinshahr Branch, Islamic Azad University, Shahinshahr, \\ Isfahan, Iran. \\ ${ }^{9}$ Department of Biological and Agricultural Engineering \&Zachry Department of Civil Engineering, Texas A \\ and M University, 321 Scoates Hall, 2117 TAMU, College Station, Texas 77843-2117, U.S.A. \\ ${ }^{10}$ Department of Civil Engineering, Isfahan (Khorasgan) Branch, Islamic Azad University, Isfahan, Iran. \\ ${ }^{11}$ Department of Agronomy and Plant Breeding, Lorestan University, Lorestan, Iran \\ ${ }^{12}$ Laboratory of Hydrology, Department of Civil Engineering, University of Thessaly, Volos, Greece \& \\ Department of Natural Resources Development and Agricultural Engineering, Agricultural University of \\ Athens, Athens, Greece.
}

*Corresponding Author: Dr. Kaveh Ostad-Ali-Askari, Department of Civil Engineering, Isfahan (Khorasgan) Branch, Islamic Azad University, University Blvd, Arqavanieh, Jey Street, P.O.Box: 81595158 Isfahan, Iran.Email: Koa.askari@khuisf.ac.ir

\begin{abstract}
To design and construct mosthydraulic structures, e.g. dams, it is essential to determine watershed runoff. If a watershed lacks any gaging station, thenhydrologic models can be utilized to estimate runoff. The Soil Water Assessment Tool (SWAT) is one of the most widelyusedcomputerwatershed models. In this model, we need to input meteorological data, such as precipitation, temperature, wind speed, solar radiation, and relative humidity; as well as watershed data, including curvenumberandroughness coefficient, to calculate the watershed runoff. Some watershedshave weather stations, but there is a risk that the recordeddataof a station do not represent the whole watershed and the use of such data may cause error. Consequently, the error of estimated runoff error needs to be determined. This study deals with the sensitivity of runoff estimatedusing the SWAT model to the variations in meteorological parameters, such as precipitation, solar radiation, wind, humidity, and temperature. Results indicate that with a $30 \%$ decrease in the average monthly precipitation, sunshine, relative humidity, wind and temperature, we witness, respectively, a $64.27 \%$ decrease, $114.67 \%$ increase, $45.93 \%$ decrease, $126.12 \%$ increase, and $39.21 \%$ increase in the estimated runoff. Runoff estimation is found to be most sensitive to wind speed and solar radiation, and least sensitive to temperature.
\end{abstract}

Keywords: meteorological parameters, rainfall runoff, sensitivity analysis, SWAT, watershed yield 


\section{INTRODUCTION}

In order to build a dam, it is vital to determinemonthly and annauwatershedyieldssothe volume of storage and the height of dam can be evaluated.. A gage station can measure the input of water to the dam. In the absence of the gage station, a computermodel, e.g. SWAT, can be used to estimate current and historical watershed runoff. However, the model requires meteorological data, such as precipitation, temperature, wind speed, solar radiation and relative humidity on one hand, and watershed charactersitics, such as curve number and roughness coefficient on the other hand. Because of the limited number of weather stations in some watersheds, the measured values of a station may not represent the whole watershed. There is therefore a need to calculate the error in runoff estimation.Thisstudy is based on, aims to investigate the sensitivity of watershed runoff estimated by SWAT to variations in meteorological parameters, such as precipitation, solar radiation, wind, humidity, and temperature.

\section{LITERATURE REVIEW}

Behtarinejad (2012) employed SWAT to investigate sedimentation and the waste of nutrients east of Gorganrood watershed.The was verified from 1999 to 2006.Datafrom 2007 to 2010 was used to validate the results which were found satisfactory. The SWAT model possesses the capability to produce diverse scenariosfordifferent management options. Gholami (2004) used SWAT to stimulate the average monthly runoff ofEmameh watershed (a sub-basin of Jajrood watershed). Results exhibited a higher sensitivity of the model to overland roughness coefficient [1-12]. Omani et al. (2007) used SWAT to stimulaterunoffin the Gharesar sub-basin northwest of the Karkheh River. They found a higher sensitivity to curve number [3-15].

Saadati (2003) stimulated daily discharge and water balance in Kasillianwatershed.Resultsshowed that the model was sensitive to the annual and monthly periods and yielded more reasonable results in comparison with the daily period (Saadati 2003).Behtarinejad (2012) and Alavinia\&Nasiri-saleh (2011)employed the SWAT model to estimate the discharge and advocated its efficiency. Applying to Ghareh-sarwatershed,Omani et al. (2008 concluded that the SWAT model was capable of stimulating hydrologic components [6-7].

Simulating runoff from Behestabad watershed (one of the sub-basins of Northern Karoon), Rostamian (2006) concluded that the SWAT model was not able to stimulatemaximumvalues [8-9].

Poorabdollah and Tajrishi (2009) employed SWAT in Emameh (a sub-basin of Latian Dam watershed) and fpimdthe model to be efficient for runoff estimation [10].

Chu and Shirmohammade (2004) used SWAT to estimate overlandflow from a 33.4 square kilometer watershed located in Maryland. Results showed that themodel was notaccurateduring very wet years. When wet years were omitted, monthly runoff was estimated satisfactorily Behtarinejad 2012, Chu \&Shirmohammade 2004) [11].

Hatou et al. (2004) concluded that the runoff values estimated by SWAT agreed with the values measured in Lershi watershed [12]. Schuol et al. (2006) argued that SWAT was capable of stimulating the hydrological balance [13-18].

Santhi et al. (2001) satisfactorily forecasted the Bask River watershed runoff by SWAT [18-34].

\subsection{Material}

The case study is limited to Kasillian watershed (located in Northern forests of Alborzmountain in Iran) that included Sangdeh, Darzikela, Sootkela, Valikchal and Valikbon villages. The area of Kasillian watershed is approximately 66.81 square kilometers and the main river stretches for 16.8 kilometers. The geographical coordinates of the watershed are: latitude from $36^{\circ}-02^{\prime}$ to $36^{\circ}-11^{\prime} \mathrm{N}$, and longitude from $53^{\circ}-10^{\prime}$ to $53^{\circ}-26^{\prime}$ E. There is a gage station on KasillianRiver at Valikbon. The station, built in 1970 , is located at longitude of $53^{\circ}-17^{\prime}$ and latitude $36^{\circ}-10^{\prime}$ to measure river discharge. Fig. 1 shows the location of Kasillian watershed. 
The SWAT model uses precipitation, temperature, solar radiation, wind speed and relative humiditydata which was available from January 1978 till January 1989. The statistical parameters were retrieved from Pol-e-sefidcineoptic, Sangdeh and Darzikelaclimatology, Valikchalprecipitationgauge, and Valik hydrometer stations.

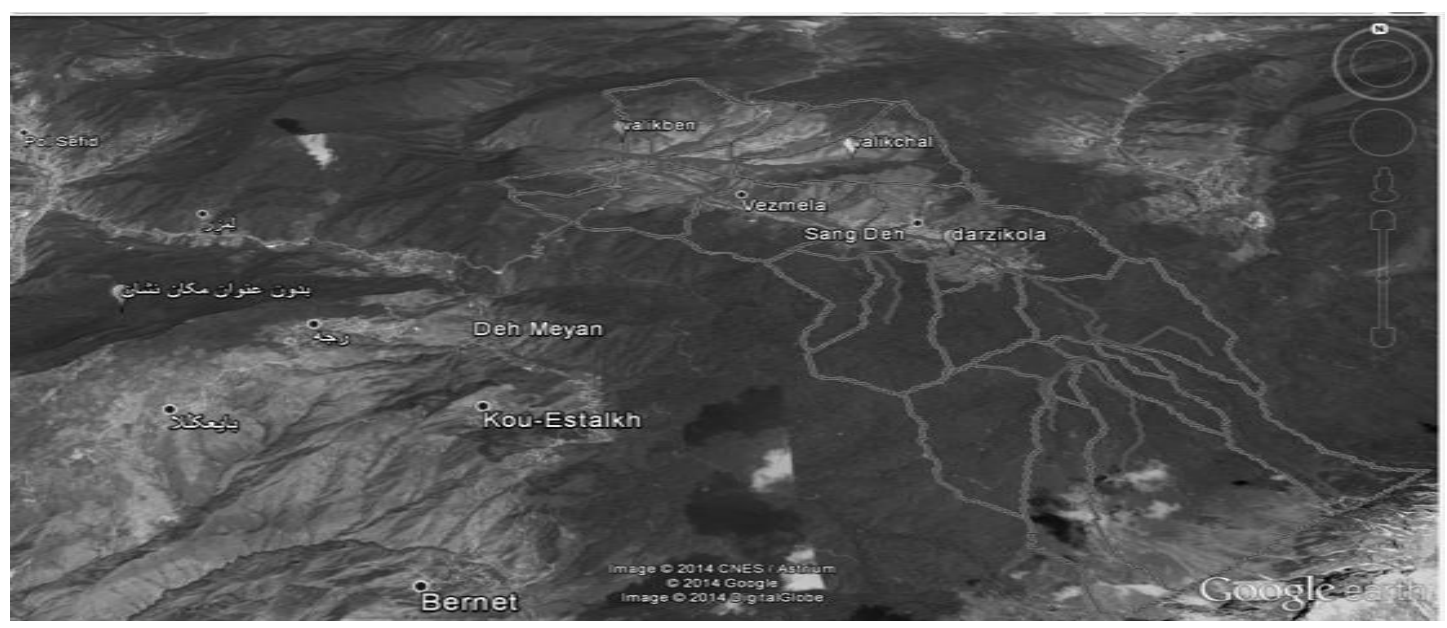

Fig1. Location of Kasilian Watershed until Valik hydrometer Station.

\subsection{SWAT Model}

SWAT was developed by the Grassland Water and Soil Research Laboratory,Temple, Texas, of the U.S. Department of Agriculture, Agricultural Research Service. This model stimulates watershed runoff and requires climatic data such as precipitation, temperature, solar radiation, wind speed and relative humidity. At least temperature and precipitation data needed to be specified and the model is able to stimulateotherdata. It also needs land map, land application, and the digital elevation model. Arc GIS software runs the SWAT model [35-66].

\subsection{Formulas and Tables}

The Soil Conservation Service (SCS) curve number is a function of soil permeability, land use,andantecedent soil moisture. Different curve numbers were considered for antecedent soil moisturecondition II in diverse types of land use from 67 to 76 based on the SWAT formulas and the optimum number for the region was obtained as 67 [67-82].

SCS runoff equation estimates runoff for different land uses and different types of soil [83-89].Equ.1 shows the runoff equation as (SCS 1972):

$Q_{\text {surf }}=\frac{\left(R_{\text {day }}-I_{a}\right)^{2}}{\left(R_{\text {day }}-I_{a}+S\right)}$

Where $\mathrm{Q}_{\text {surf }}$ is the accumulated runoff or the excess of precipitation $(\mathrm{mm}), \mathrm{R}_{\text {day }}$ is the amount of precipitation per day $(\mathrm{mm}), \mathrm{I}_{\mathrm{a}}$ is the initial abstraction of the surface reserve, the diffusion before runoff $(\mathrm{mm})$, and $\mathrm{S}$ is the maximum soil moisture retention $(\mathrm{mm})$. A changeinthe $\mathrm{S}$ parameter results from change in the soiltype, land use, management, slope and soil content. The Sparameteris defined in Equ.2 (SWAT Theoretical Documentation Version 2009):

$S=25.4\left(\frac{1000}{C N}-10\right)$

where $\mathrm{CN}$ is the curve number for day. $\mathrm{I}_{\mathrm{a}}$ is approximately estimated as 0.2 and fed into Equ.1.to obtain Equ.3 (SWAT Theoretical Documentation Version 2009):

$Q_{\text {surf }}=\frac{\left(R_{\text {day }}-0.2 s\right)^{2}}{\left(R_{\text {day }}+0.8 s\right)}$

Runoff occurs onlyif $R_{\text {day }}>I_{a}$. The graphical solutions for Equ.3 with the numerical values of different curves are presented in Fig.2 (SWAT Theoretical Documentation Version 2009). As evident 
in Fig.2, the higher the curve number, the more precipitationbecomesrunoff. The runoff resulting from precipitationvarieswith a curve according to the curvenumber.

The SCS curve defines three antecedent moisture conditions: 1- dry (wilting point), 2- average antecedent moisture, and 3- wet (soil capacity). The humidity condition 1 (dry) possesses the lowest value in the daily curve number. The curve numbers for antecedent moisture conditions $1 \& 2$ are calculated based on equations 4\& 5 (SWAT Theoretical Documentation Version 2009):

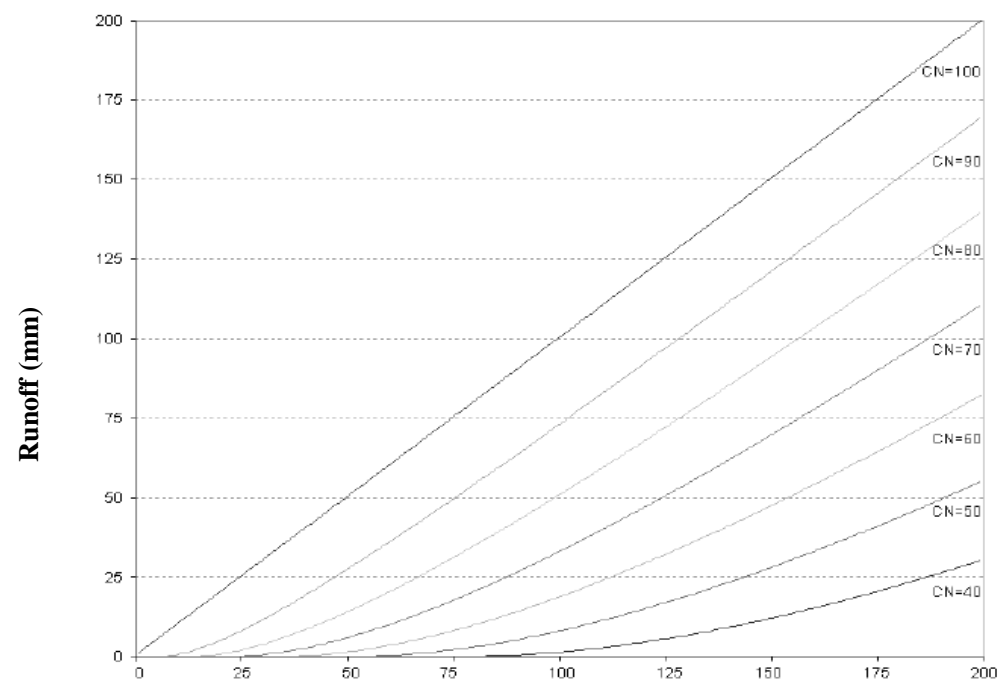

Fig2. Relationship of runoff to rainfall in SCS Curve number method.(SWAT Theoretical Documentation Version 2009

$$
\begin{aligned}
& \mathrm{CN}_{1}=\mathrm{CN}_{2}-\frac{20 \cdot\left(100-\mathrm{CN}_{2}\right)}{\left(100-\mathrm{CN}_{2}+\exp \left[2.533-0.0636 .\left(100-\mathrm{CN}_{2}\right)\right]\right)} \\
& \mathrm{CN}_{3}=\mathrm{CN}_{2} \cdot \exp \left[0.00673 .\left(100-\mathrm{CN}_{2}\right)\right]
\end{aligned}
$$

Where $\mathrm{CN}_{1}, \mathrm{CN}_{2}$ and $\mathrm{CN}_{3}$ are the curvenumbers for antecedent soil moisture conditions 1, 2 and 3, respectively.

Williams (1995) developed a curve number equation for different slopes as Equ.6 (SWAT Theoretical Documentation Version 2009):

$$
\mathrm{CN}_{2 \mathrm{~s}}=\frac{\left(\mathrm{CN}_{3}-\mathrm{CN}_{2}\right)}{3} \cdot[1-2 \cdot \exp (-13.86 . \mathrm{slp})]+\mathrm{CN}_{2}
$$

Where $\mathrm{CN}_{2 \mathrm{~s}}$ (for the antecdedent soil moisture condition II) is set for the slope, $\mathrm{CN}_{3}$ (for the antecedent soil moisture condition III) is for a $5 \%$ slope, $\mathrm{CN}_{2}$ (for the antecedent soil moisture condition II) is for a 5\% slope and SLP is the average slope of sub-basins. SWAT does not set the curve numbers for the slope. Setting is done before entering the curve number and through the input file management. SWAT input variables, utilizing the curve number method, affects the overland runoff calculation as in table1 (SWAT Theoretical Documentation Version 2009):

\begin{tabular}{|c|c|c|}
\hline Variable Name & Definition & Input File \\
\hline IEVENT & Rainfall, runoff, routing option. &.$b s n$ \\
\hline ICN & $\begin{array}{l}\text { Daily curve number calculation method:0 caculate daily } \mathrm{CN} \\
\text { value as a function of soil moisture } \leqslant 1 \text { calculate daily } \mathrm{CN} \\
\text { value as a function of plant evapotranspiration }\end{array}$ &.$b s n$ \\
\hline CNCOEF & $\begin{array}{l}\text { Cncoef: Weihghting coefficient used to calculate the } \\
\text { retention coefficient for daily curve number calculations } \\
\text { dependent on plant evapotranspiration }\end{array}$ & .bsn \\
\hline PERCIPITATION & $\mathrm{R}_{\text {day }}$ : Daily precipitation $\left(\mathrm{mm} \mathrm{H}_{2} \mathrm{O}\right)$ & .pcp \\
\hline $\mathrm{CN}_{2}$ & $\mathrm{CN}_{2}$ : Moisture condition II curve number & mgt \\
\hline CNOP & $\mathrm{CN}_{2}$ : Moisture condition II curve number & mgt \\
\hline
\end{tabular}

Table1. SWAT input variables that pertain to surface runoff calculated with the SCS curve number method.(SWAT Theoretical Documentation Version, 2009) 
The Manning overland roughness coefficient values for the intended watershed region and related SWAT tables are in the range of .05 to .2. The optimum value for this region was calculated as 1 [90114].

The overland concentration timet ${ }_{\mathrm{ov}}$ was calculated by Equ.7 (SWAT Theoretical Documentation Version 2009):

$t_{o v}=\frac{L_{s l p}}{3600 \cdot v_{o v}}$

Where $\mathrm{L}_{\mathrm{slp}}$ is the length of sub-basin slope, $\mathrm{v}_{\mathrm{ov}}$ is the velocity of overland flow $(\mathrm{m} / \mathrm{s})$, and 3600 is the unit conversion factor. The velocity of overland flow was estimated based on Equ. 8 or Manning equation (SWAT Theoretical Documentation Version 2009):

$v_{o v}=\frac{q^{0.4}{ }_{o v} \cdot s l p^{0.3}}{n^{0.6}}$

Where $\mathrm{q}_{\mathrm{ov}}$ is the average of the land current (cubic meter per second),slp is the mean slope of subbasin, and $n$ is the Manning roughness coefficient for the sub-basin. The rate of current is assumed as $6.35 \mathrm{~mm} / \mathrm{h}$ and unit conversion was done through Equs. 9 and 10 (SWAT Theoretical Documentation Version 2009).

$v_{o v}=\frac{0.005 \cdot L_{s l p}^{0.4} \cdot s l p^{0.3}}{n^{0.6}}$

$t_{o v}=\frac{L_{s l p}^{0.6} \cdot n^{0.6}}{18 . \operatorname{slp}^{0.3}}$

\subsection{Soil Type}

In this study, we used the optimum curve number and overland roughness coefficient. The precipitation data was chosen from different meteorological stations to obtain the optimum curve number and overland roughness coefficient. SWAT was initially run with the curve number $\mathrm{CN}_{2}=67$ and the overlandroughness coefficient of 0.1 . Results are presented in fig. 3 .

To optimize parameters, different values of the curve numberand roughness coefficient were utilized and the correlation of discharge variation with each parameter introduced in tables 2 and 3is represented in figures 4 to 7 . By comparisonof runoff amounts registered at the hydrometer station with the calculated amount, the most optimum curve number was found to be 67 and the roughness coefficient as .1. Subsequently, based on thesevalues, variations in the SWAT input parameters were used to simulatethewatershed runoff. The effect of variation in each of meteorological parameters on runoff was calculated and compared with the observed runoff. It should be mentioned that in this stage of calculations only precipitation data were fed into the model [115-127].

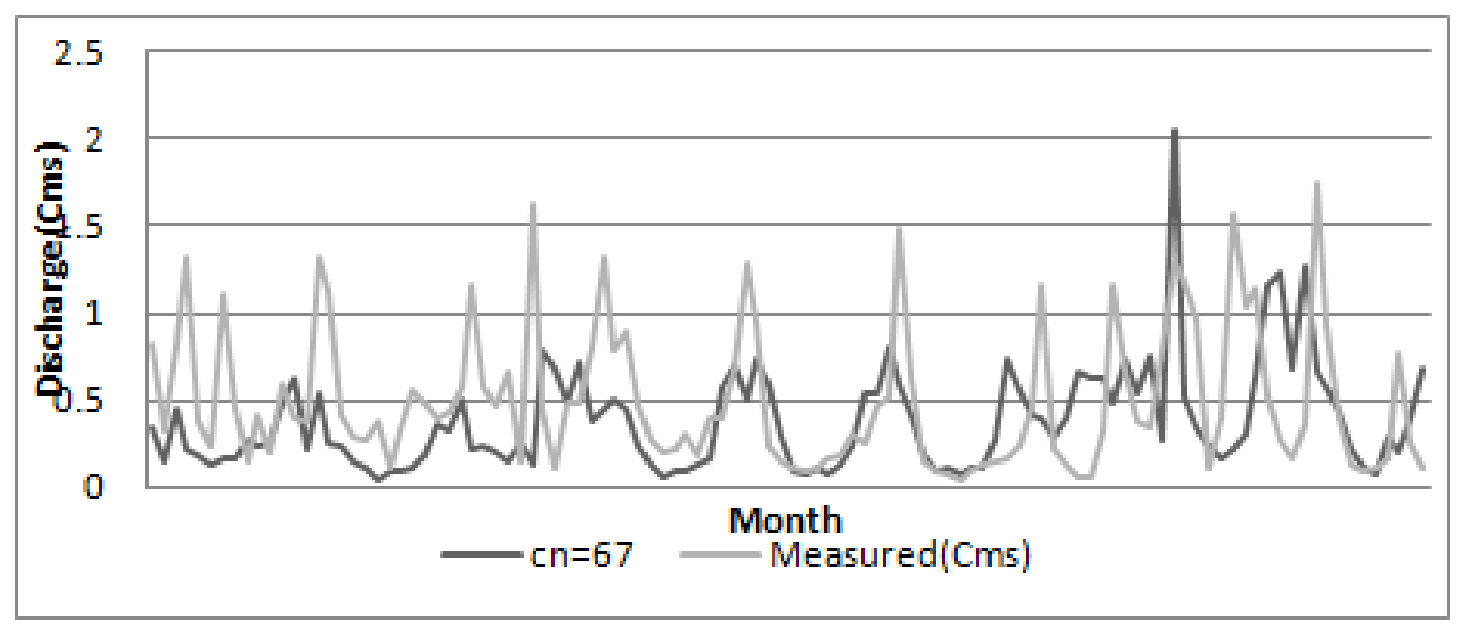

Fig3. Comparison ofMonthly Simulated Discharge of the SWAT with Measured Discharge. 
Sensitivity Analysis of Runoff Model by SWAT to Meteorological Parameters: A Case Study of Kasillian Watershed, Mazandaran, Iran

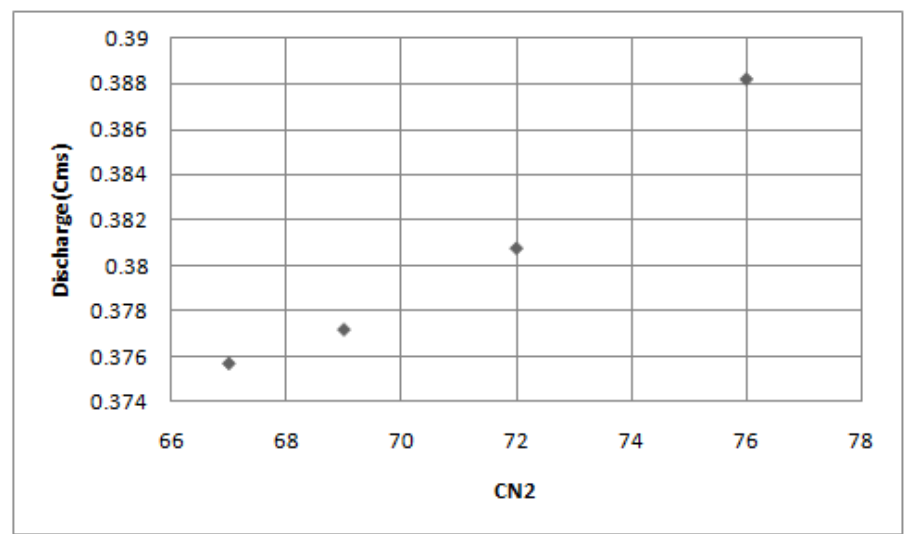

Fig4. Simulated discharge for different values of $\mathrm{CN}_{2}$

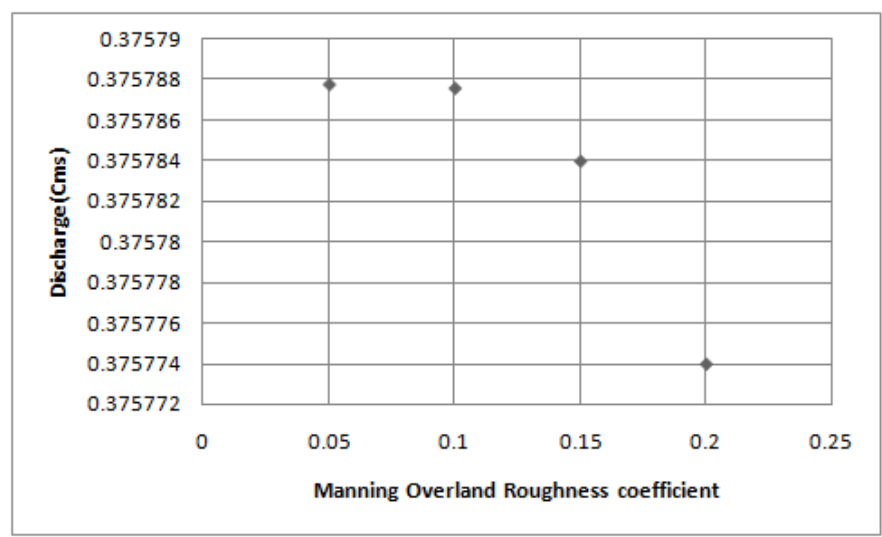

Fig5. Simulated discharge for difference Manning overland roughness coefficient values

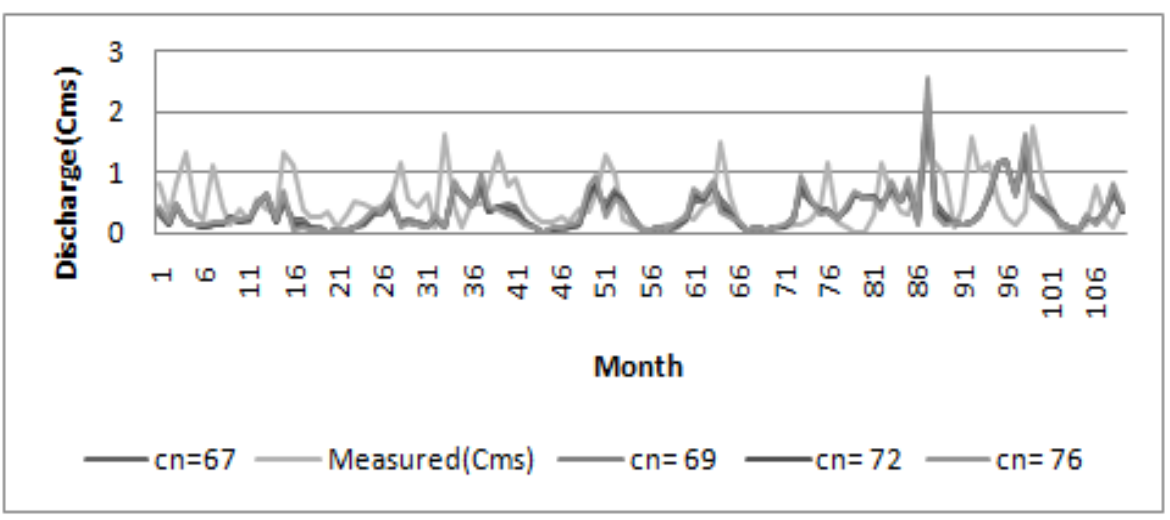

Fig6. Comparison of simulated discharge river with different $C N$ values with measured discharge

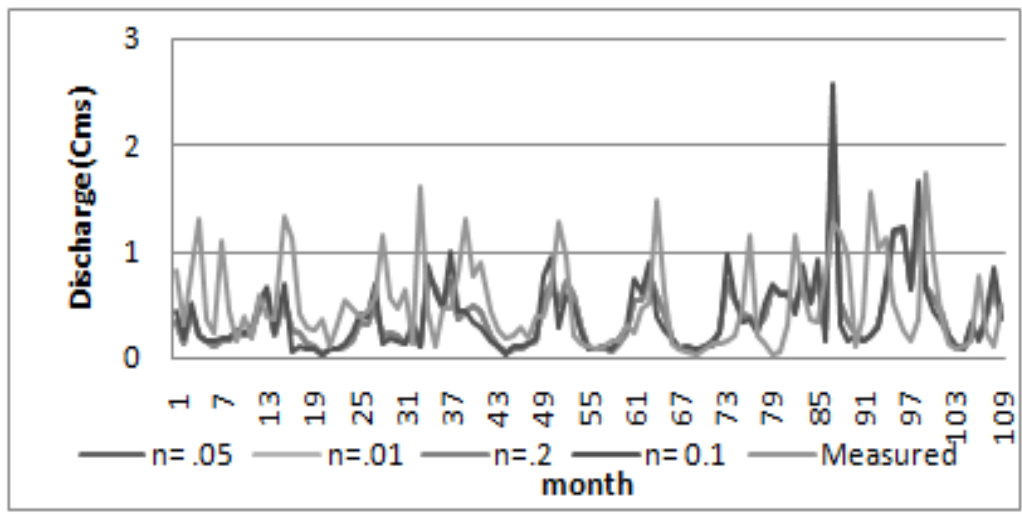

Fig7. Comparison of simulated discharge with different Manning overland eoughness coefficient values with maesured discharge 
Sensitivity Analysis of Runoff Model by SWAT to Meteorological Parameters: A Case Study of Kasillian Watershed, Mazandaran, Iran

Table2. Effect of $C N$ on averagesimulated discharge

\begin{tabular}{|c|c|c|c|c|}
\hline CN & $\mathbf{6 7}$ & $\mathbf{6 9}$ & $\mathbf{7 2}$ & $\mathbf{7 6}$ \\
\hline Average Simulated Discharge $\left(\mathrm{m}^{3} / \mathrm{s}\right)$ & 0.375787 & 0.377227 & 0.38084 & 0.388203 \\
\hline Average Measured Discharge $\left(\mathrm{m}^{3} / \mathrm{s}\right)$ & 0.498953 & 0.498953 & 0.498953 & 0.498953 \\
\hline Error $\left(\mathrm{m}^{3} / \mathrm{s}\right)$ & 0.123166 & 0.121726 & 0.118113 & 0.11075 \\
\hline Percent change or variable & 0 & $0.3992 \%$ & $1.3574 \%$ & $3.3271 \%$ \\
\hline
\end{tabular}

\subsection{Sensitivity Analysis of Watershed Runoff to Meteorological Parameters}

Required meteorological parameters, including temperature, relative humidity, wind speed,solar radiation, and precipitation were fed into SWAT and average runoff, as is shown in the third row of table 4 , was calculated as 0.5704 cubic meters per second.

Table4. Simulated discharge for varing preiciptation

\begin{tabular}{|c|c|c|c|c|}
\hline 兽兽. & 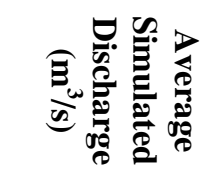 & 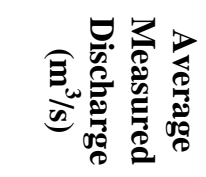 & 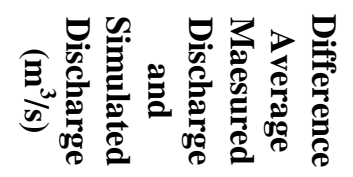 & 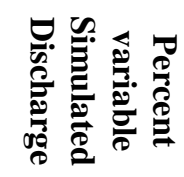 \\
\hline $\mathrm{PCP} \times 1.5=3.11181$ & 1.285224074 & 0.49895304 & 0.7863 & $125.31 \%$ \\
\hline $\mathrm{PCP} \times 0.7=1.452178$ & 0.203889444 & 0.49895304 & 0.2951 & $-64.27 \%$ \\
\hline $\mathrm{PCP}=2.07454$ & 0.5704225 & 0.49895304 & 0.0715 & 0 \\
\hline
\end{tabular}

\subsection{Effect of Precipitation}

In order to evaluate the sensitivity of runoff estimated by the SWAT model to precipitation, initially all precipitation values were multipliedby 1.5 and runoff was calculated. The real amount of precipitation was used to obtain the average long-term runoff (.570). With a 50\% increase in precipitation, runoff increased to 1.285 (a $125 \%$ increase). With a $30 \%$ decrease in precipitation, the average runoff decreased by $64 \%$ (.204 cubic meters per second). Consequently, we obtained a .7148 increase and a .3666 decrease in monthly runoff. As evident in Fig.8, the monthly runoff trend was ascending based on precipitation. With a 50\% increase and a 30\% decrease in input precipitation, the stimulated runoff was .79 and .29 whichwere higher and lower than the average observed monthly runoff, respectively [128-143].

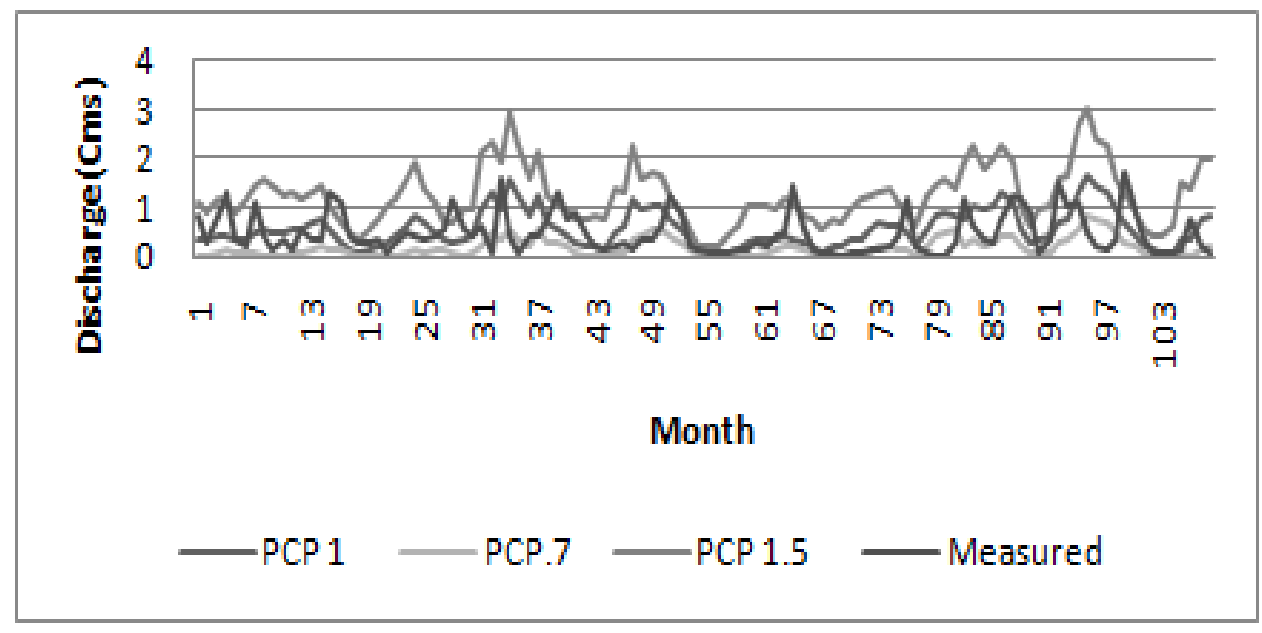

Fig8. Simulated Discharge for varying precipitation

\subsection{Effect of Solar Radiation}

For a $20 \%$ increase and a $30 \%$ decrease in solar radiation, the simulated runoff varied from 0.57 cubic meters per second to 0.59 and 1.22 cubic meters per second, respectively. The monthly variations are presented in table 5 and figures 10 and 11, with a 20\% increase and a 30\% decrease in solar radiation, the simulated runoff increased by 0.09 and 0.73 cubic meters per second, repectively [144-159]. 
Table5. Simulated Discharge for different solar radiation values

\begin{tabular}{|c|c|c|c|c|}
\hline 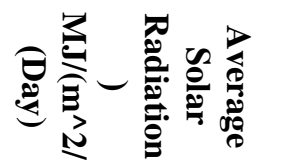 & 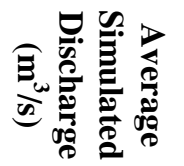 & 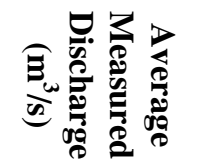 & 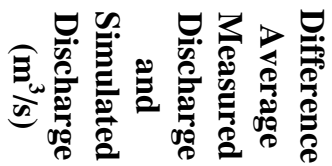 & 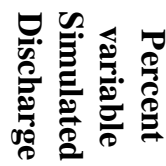 \\
\hline solar $\times 1.2=22.16$ & 0.59279263 & 0.498653704 & 0.0938 & $3.9095 \%$ \\
\hline solar $\times 0.7=12.901$ & 1.224596 & 0.498653704 & 0.7256 & $114.67 \%$ \\
\hline solar $=18.43$ & 0.5704225 & 0.498653704 & 0.0715 & 0 \\
\hline
\end{tabular}

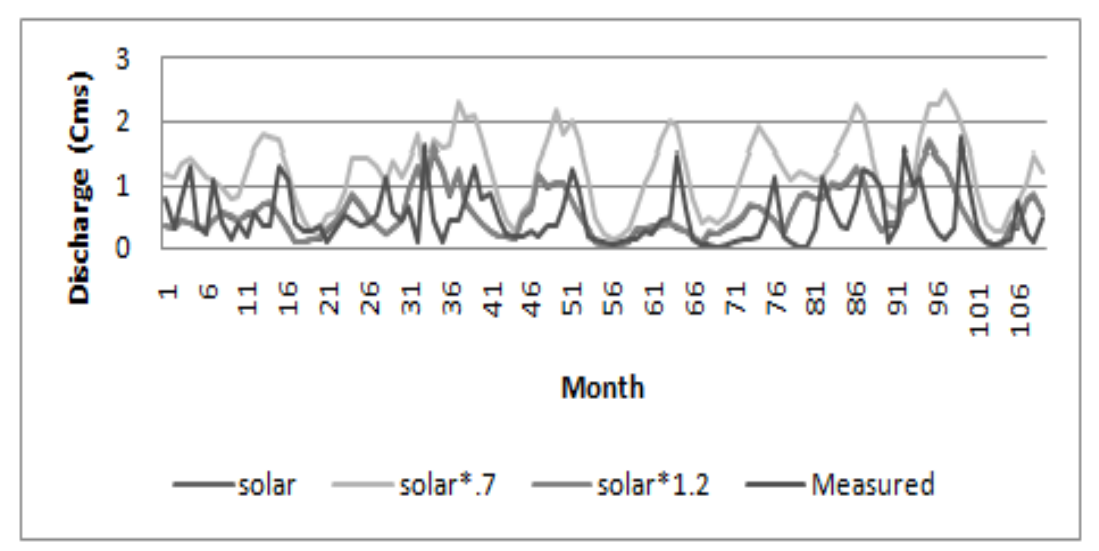

Fig10. Simulated Discharge for different solar radiation

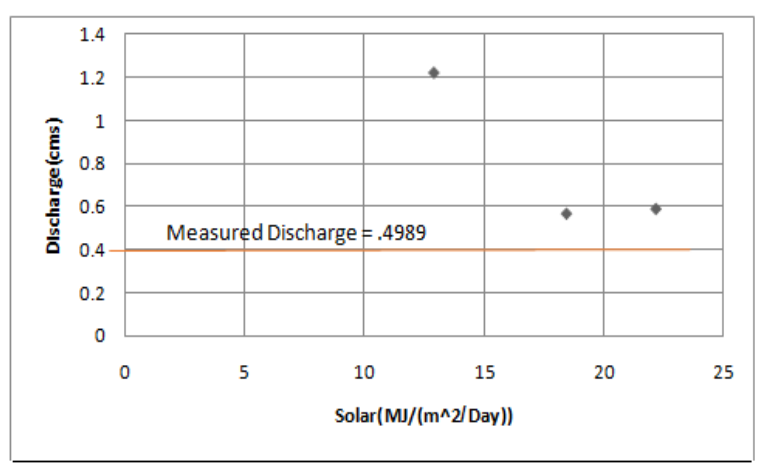

Fig11. Average monthly simulated discharge for different solar radiation values

\subsection{Effect of Relative}

With a $20 \%$ increase and a $30 \%$ decrease in relative humidity, the average monthly runoff changed from .5704 to .6947 and .3084 , respectively. The $21.79 \%$ increase and $45 \%$ decrease are presented in table 6and figures 12 and 13 . With a $20 \%$ increase and $30 \%$ decrease in relative humidity, the simulated runoff was $39.25 \%$ higher, and $38.18 \%$ lower than average measured monthly runoff, respectively [160-178].

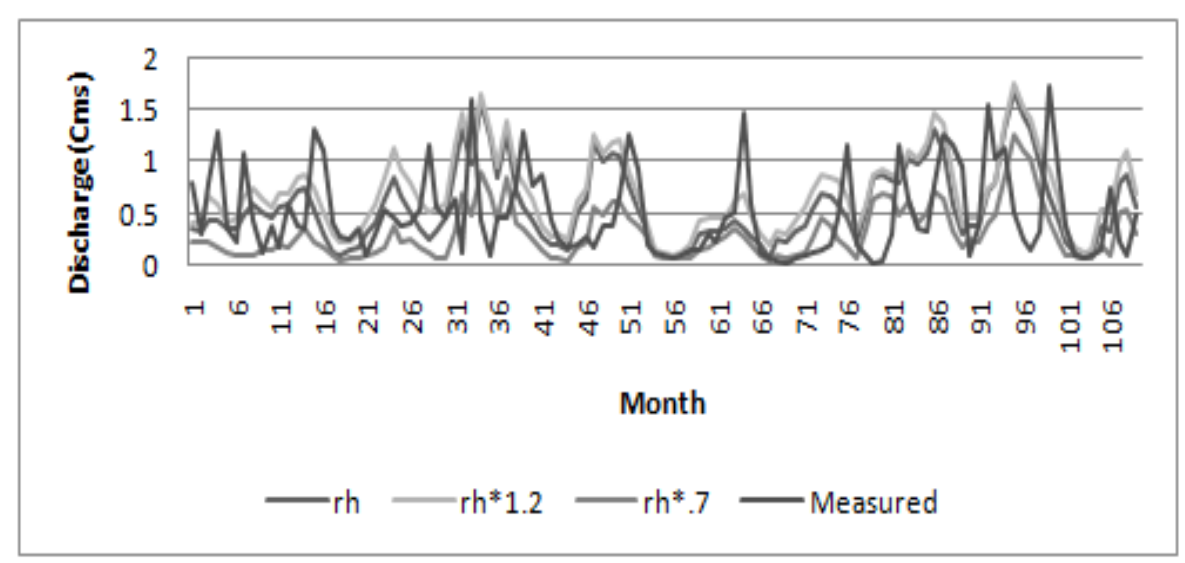

Fig12. Average monthly simulated discharge with varying relative humidity 
Sensitivity Analysis of Runoff Model by SWAT to Meteorological Parameters: A Case Study of Kasillian Watershed, Mazandaran, Iran

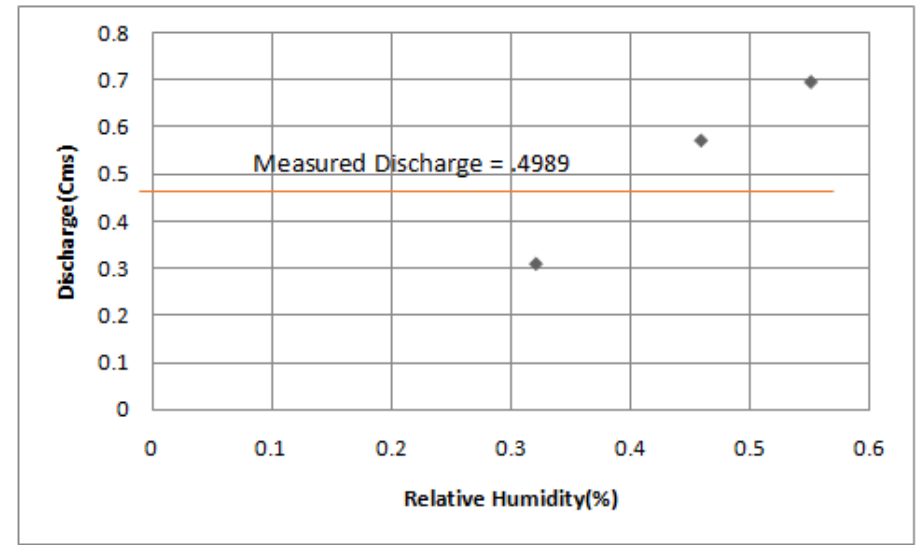

Fig13. Simulated discharge for varying relative humidity

Table6. Simulated Discharge with varying relative humidity

\begin{tabular}{|c|c|c|c|c|}
\hline 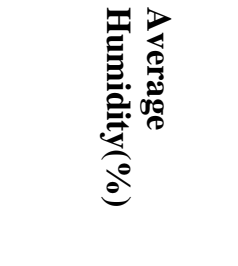 & 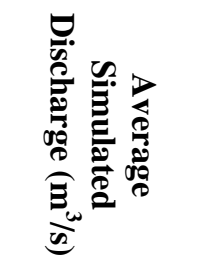 & 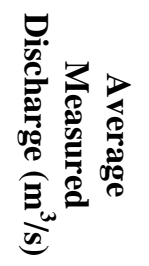 & 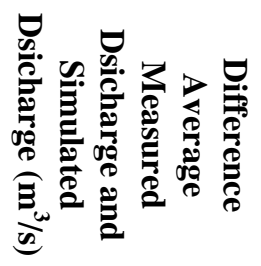 & 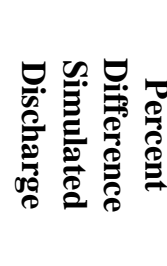 \\
\hline $\mathrm{Rh}=0.4591$ & 0.5704225 & 0.498953 & 0.0715 & 0 \\
\hline $\mathrm{Rh} \times 1.2=0.5509$ & 0.694742037 & 0.498953 & 0.1958 & $21.79 \%$ \\
\hline $0.7 \mathrm{Rh} \times=0.3213$ & 0.308425093 & 0.498953 & 0.1905 & $-45.93 \%$ \\
\hline
\end{tabular}

\subsection{Effect of Wind Speed}

With a 50\% increase and a 30\% decrease in wind speed, the average monthly runoff was 1.23 and 1.28 cubic meters per second. The simulated values were .74 and .79 higher than the observed average monthly runoff (figures $14 \& 15$, table 7).

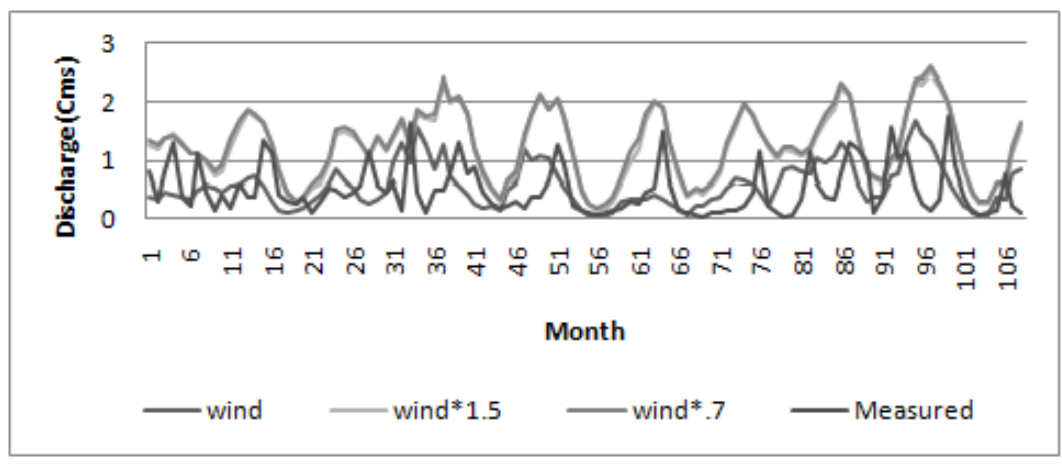

Fig14. Simulated discharge for varying wind speed

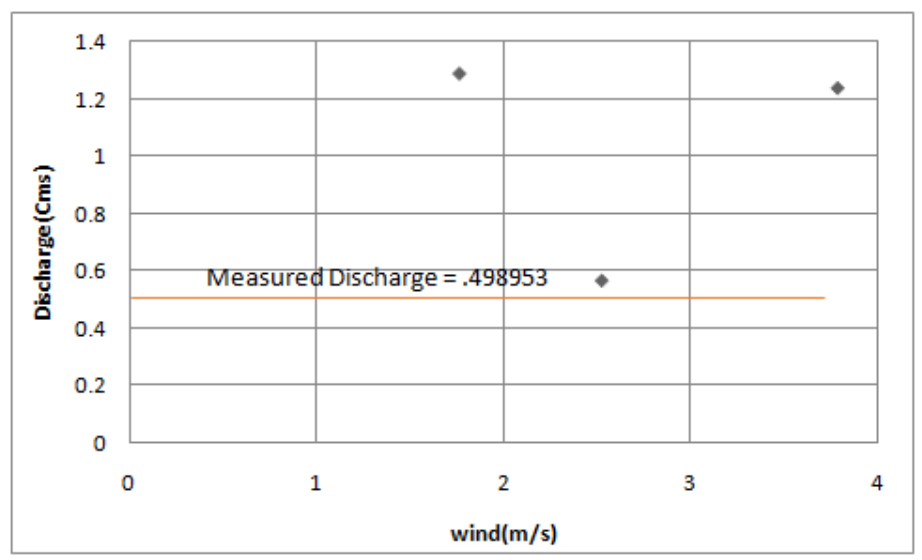

Fig15. Simulated discharge for varying wind speed 
Table7. Measureddischarge and simulateddischargefor different wind speed

\begin{tabular}{|c|c|c|c|c|}
\hline 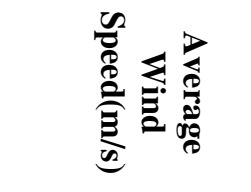 & 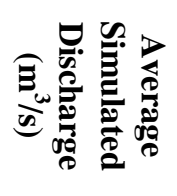 & 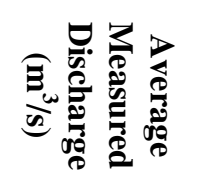 & 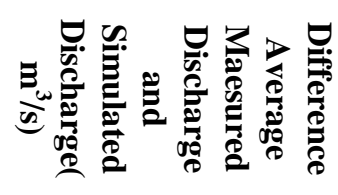 & 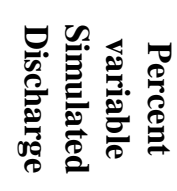 \\
\hline 0.7 wind $x=1.764$ & 1.2898388 & 0.498953704 & 0.7909 & $126.12 \%$ \\
\hline 1.5 wind $x=3.78$ & 1.23933713 & 0.498953704 & 0.7404 & $117.26 \%$ \\
\hline Wind $=2.52$ & 0.5704225 & 0.498953704 & 0.0715 & \\
\hline
\end{tabular}

\subsection{Effect of Temperature}

With a $50 \%$ increase and a $30 \%$ decrease in temperature, the average monthly runoff varied from .570 to .242 and .794 , that is, a $57.56 \%$ increase and a $39.21 \%$ decrease in monthly runoff. The Simulated results were $51 \%$ lower and $61.22 \%$ higher than the measuredaveragemonthly runoff (figures $16 \&$ 17 , table 8).

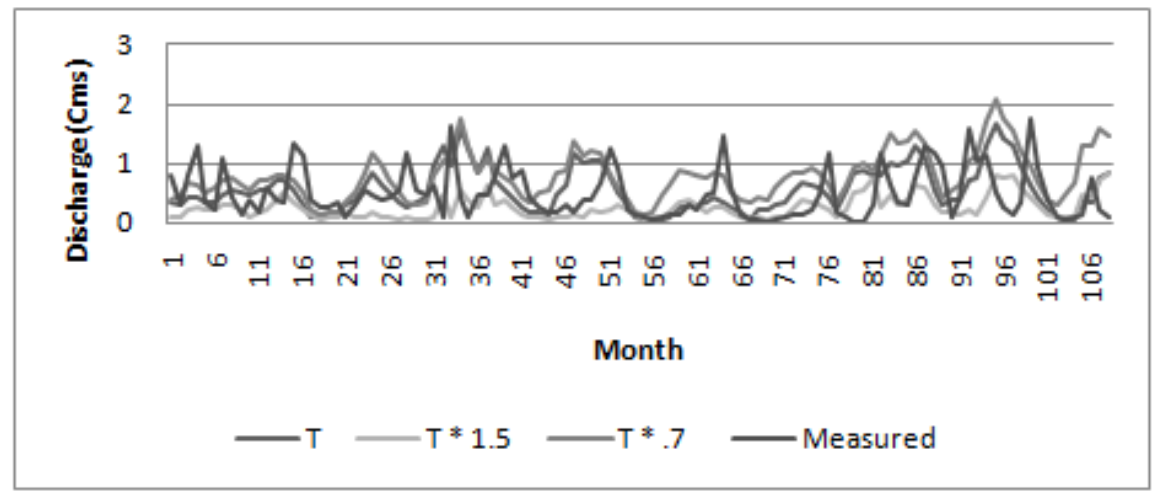

Fig16. Simulated discharge for varying temperature

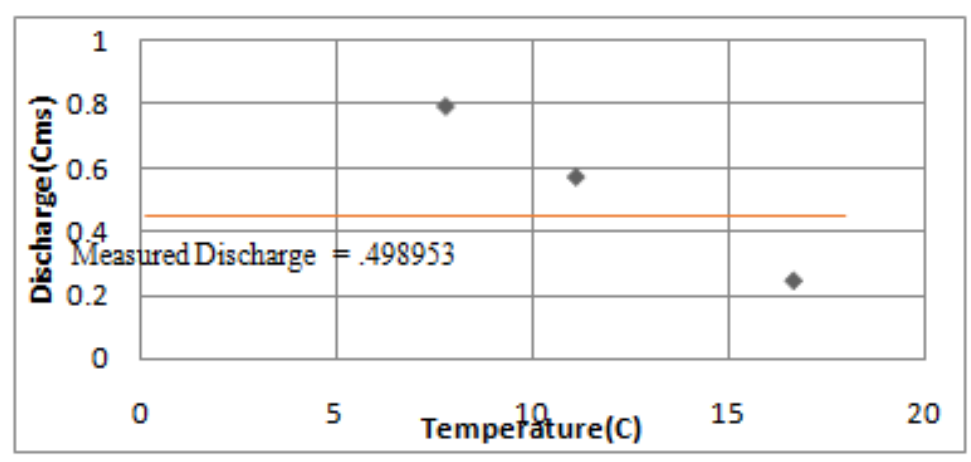

Fig17. Simulated discharge for varyingtemperature

Table8. Simulated discharge for varying temperature

\begin{tabular}{|c|c|c|c|c|}
\hline Temperature(C) & 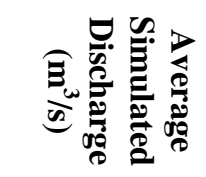 & 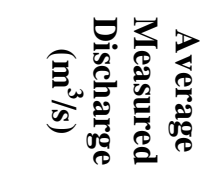 & 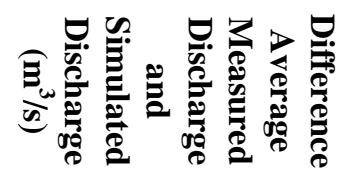 & 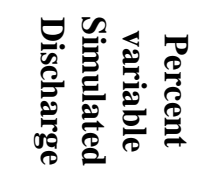 \\
\hline $\mathrm{T} \times 0.7=7.76$ & 0.79410463 & 0.498953704 & 0.2952 & $39.21 \%$ \\
\hline $\mathrm{T} \times 1.5=16.635587$ & 0.242062685 & 0.498953704 & 0.2569 & $-57.57 \%$ \\
\hline $\mathrm{T}=11.08963$ & 0.5704225 & 0.498953704 & 0.0715 & 0 \\
\hline
\end{tabular}

\section{RESUltS}

1. With a $13.43 \%$ increase in the curve number, the simulated average monthly runoff would be $2.51 \%$ close to the measured average runoff. With a $1.5 \%$ increase in the roughness coefficient of watershed, the simulated runoff would come $.01 \%$ closer to the measured discharge. 
2. A $30 \%$ decrease in average monthly precipitation, solar radiation, relative humidity, wind and temperature would cause a $64.27 \%$ decrease, $114.67 \%$ increase, $45.93 \%$ decrease, $126.12 \%$ increase and $39.21 \%$ increase in average monthly runoff, respectively. It is evident that precipitation and relative humidity produce the most decreases. The most increase in runoff was a function of wind, then solar radiation and finally temperature.

3. With a $50 \%$ increase in the average monthly precipitation, a $20 \%$ increase in radiation and relative humidity and a 50\% increase in wind and temperature, the runoff amount would experience a $125.31 \%$ increase, $3.9095 \%$ increase, $21.79 \%$ increase, $117.26 \%$ increase and $57.57 \%$ decrease, respectively. Precipitation then wind and relative humidity cause the most increases. Runoff is least sensitive to solar radiation.

\section{REFERENCES}

[1] Alavinia.M,NasiriSaleh.F;(2010).Comparsion Of HSPF and SWAT Model to simulate Sediment;(Case Study: Watershed Abro); Fifth National Congress On Civil Engineering Ferdowsi University Of Mashhad.

[2] BehtariNejad.B,(2011).Estimation of erosion, sedimentation and nutrient loss in Gorganrood catchment with SWAT model.A Thesis Presented for a Degree Master of Science(M.Sc) in Soil Physics \& Conservation.

[3] Chu, T.W .andShirmohammadi, A , 2004. Evaluation of the SWAT model's hydrology component in the piedmont physiographic region of Maryland. Trans. ASAE.47: 1057-1073.

[4] Engman, E.T. 1983. Roughness coefficients for routing surface runoff. Proc Spec. Conf. Frontiers of Hydraulic Engineering.

[5] Gholami,Sh.2003. Simulation of Daily Sediment using Distribuation SWAT Model in Mountain Catchment ( Case Study: Catchment Emameh). Quarterly Research and Development.

[6] Hao, F .H ,.Zhang, X.S. and Yang , Z. F. 2004. A distributed nonpoint- source pollution model: Calibration and validation in the Yellow River basin. J. Environ. Sci.16(4): 646-650.

[7] Omani.N, Tajrishy.M ,Abrishamchie.A.;(2007).StreamflowSimulation Using Of SWAT and GIS Model. Seventh International Seminar Of River Engineering;ShahidChamran University Of Ahvaz.

[8] Pourabdullah.M, Tajrishy.M.;(2006).Erosion Catchment Model with SWAT \&Rusle Model.(Case Study: Emameh Sub-Catchment). Seventh International Conference Of Civil Engineering.

[9] Rallison,R,E. and N.Miller .1981.Past, present and future SCS runoff procedure.p. 353-364. In V.P. Singh (ed). Rainfall runoff relationship. Water Resources Publication, Littleton, CO.

[10] Rostamian R, Mousavi S, Heidarpour M, Afyuni M, Abaspour K.,(2006).Apllication Of SWAT 2000 Model For Estimating Runoff and Sediment In Beheshtabad, Sub-basin Of Northern Karun.A Thesis Presented for a Degree Master of Science(M.Sc) in Geology,Faculty Of Agriculture;Isfahan University Of Technology.

[11] Saadati.H,(Fall 2002); Effect Of Land Use On Simulating Daily Discharge Flow Using SWAT Mathematical Model (Case Study : Kasilian Catchment Area); A Thesis Presented For The Degree Of Master in Watershed Management.; TarbiatModares University Natural Science Faculty.

[12] Santhi, C., Arnold,J.G.,Williams, J.R., Dugas,W.A., Srinivasan, R and Hauck, L. M.(2001). Validation of the SWAT model on a large river basin with point and nonpoint sources. Journal of American Water Resources Association 37:1169-1188.

[13] Schuol, J ., Abbaspour, K .C . Yang, H. Reichert ,P . Srinivasan, R. ScharCh.andZehnder , A.J.B.2006. Estimation of freshwater availability in the west Africa subcontinent. J . Hydrol.254:58-69.

[14] Soil Conservation Service. 1964. Chapter 17 : Flood routing, Section 4, Hydrology , National engineering handbook. U.S. Department of Agriculture.U.S.Gov't Printing Office, Washington, D.C.

[15] Soil Conservation Service. 1972.Section 4: Hydrology In National Engineering Handbook.SCS.

[16] Soil Conservation Service Engineering Division.1986.Urban hydrology for small watersheds.U.S. Department of Agriculture, Technical Release 55.U

[17] Talebizadeh.M,( Winter 2009).Daily Sediment Load Estimation Using The SWAT Model and Artificial Neural Network;CaseStudy:Kasilian Watershed.; TarbiatModares University Natural Science Faculty.

[18] USDA Soil Conservation Service.1972. National Engineering Handbook Section 4 Hydrology , Chapter 410.

[19] USDA Soil Conservation Service.1983. National Engineering Handbook Section 4 Hydrology , Chapter 19. 
[20] Ostad-Ali-Askari, K., Shayannejad, M. 2015, Study of sensitivity of Autumnal wheat to under irrigation in Shahrekord, Shahrekord City, Iran. International Journal of Agriculture and Crop Sciences, 8 (4), 602-605.

[21] Shayannejad, M., Akbari, N., Ostad-Ali-Askari, K. 2015, Study of modifications of the river physical specifications on muskingum coefficients, through employment of genetic algorithm. International Journal of Development Research, 5(3), 3782-3785.

[22] Ostad-Ali-Askari, K., Shayannejad, M. 2015, The Reviews of Einstein's Equation of Logarithmic Distribution Platform and the Process of Changes in the Speed Range of the Karkheh River, Khuzestan province, Iran. International Journal of Development Research, 5(3), 3786-3790.

[23] Ostad-Ali-Askari, K., Shayannejad, M., Ghorbanizadee-Kharazi, H. 2015, Assessment of artificial neural network performance and exponential regression in prediction of effective rainfall, International Journal of Development Research, 5(3),3791-3794.

[24] Shayannejad, M. Akbari, N. and Ostad-Ali-Askari, K. 2015, Determination of the nonlinear Muskingum model coefficients using genetic algorithm and numerical solution of the continuity. Int. J. of Science: Basic and Applied Research, 21(1),1-14.

[25] Ostad-Ali-Askari, K., Shayannejad, M. 2015, The Study of Mixture Design for Foam Bitumen and the Polymeric and Oil Materials Function in Loose Soils Consolidation. Journal of Civil Engineering Research, 5(2), 39-44. DOI: 10.5923/j.jce.20150502.04

[26] Sayedipour, M., Ostad-Ali-Askari, K., Shayannejad, M. 2015, Recovery of Run off of the Sewage Refinery, a Factor for Balancing the Isfahan-Borkhar Plain Water Table in Drought Crisis Situation in Isfahan Province-Iran. American Journal of Environmental Engineering, 5(2): 43-46. DOI: 10.5923/j.ajee.20150502.02

[27] Ostad-Ali-Askari, K., Shayannejad, M. 2015, Developing an Optimal Design Model of Furrow Irrigation Based on the Minimum Cost and Maximum Irrigation Efficiency. International Bulletin of Water Resources \& Development, 3(2), 18-23.

[28] Ostad-Ali-Askari, K., Shayannejad, M. 2015, Presenting a Mathematical Model for Estimating the Deep Percolation Due to Irrigation. International Journal of Hydraulic Engineering, 4(1), 17-21. DOI: 10.5923/j.ijhe.20150401.03.

[29] Ostad-Ali-Askari, K., Shayannejad, M. 2015, Usage of rockfill dams in the HEC-RAS software for the purpose of controlling floods. American Journal of Fluid Dynamics, 5(1), 23-29. DOI: 10.5923/j.ajfd.20150501.03.

[30] Soltani, A. R., Ostad-Ali- Askari, K., Shayannejad, M. 2015, The effect of heterogeneity due to inappropriate tillage on water advance and recession in furrow irrigation. Journal of Agricultural Science, 7(6), 127-136.

[31] oltani, A. R., Shayannejad, M., Ostad-Ali-Askari, K. 2015, Effects of magnetized municipal effluent on some chemical properties of soil in furrow irrigation. International Journal of Agriculture and Crop Sciences, 8(3), 482-489.

[32] Ostad-Ali-Askari, K., Shayannejad, M. 2015, Optimal design of pressurized irrigation laterals installed on sloping land. International Journal of Agriculture and Crop Sciences, ISSN 2227-670X. 8(5), 792-797.

[33] Ostad-Ali-Askari K, Shayannejad M, Eslamian S, Navab-Pour B. 2016, Comparison of solution of SaintVenant equations by characteristics and finite difference methods for unsteady flow analyzing in open channel. International Journal of Hydrology Science and Technology, 6(3), 9-18.

[34] Ostad-Ali-Askari K, Shayannejad M, Eslamian S, et al. 2017, Deficit Irrigation: Optimization Models. Management of Drought and Water Scarcity.Handbook of Drought and Water Scarcity, Taylor \& Francis Publisher, USA.Vol. 3.1 ${ }^{\text {th }}$ Edition, pp: 373-389.

[35] Eskandari S, Hoodaji M, Tahmourespour A, Abdollahi A, Mohammadian-Baghi T, Eslamian S, Ostad-AliAskari K. 2017, Bioremediation of Polycyclic Aromatic Hydrocarbons by Bacillus Licheniformis ATHE9 and Bacillus Mojavensis ATHE13 as Newly Strains Isolated from Oil-Contaminated Soil. Journal of Geography, Environment and Earth Science International, 11(2): 1-11.

[36] Shayannejad M, Soltani A.R, Ostad-Ali-Askari K, Eslamian S, et al. 2017, Development of a new method for determination of infiltration coefficients in furrow irrigation with natural non-uniformity of slope. Sustain. Water Resour. Manag., 3(2): 163-169.

[37] Shojaei N, Shafaei-Bejestan M, Eslamian S, Marani-Barzani M, P. Singh V, Kazemi M, Ostad-Ali-Askari K. 2017, Assessment of Drainage Slope on the Manning Coarseness Coefficient in Mountain Area. International Journal of Constructive Research in Civil Engineering (IJCRCE), 3(1): 33-40.

[38] Bahmanpour H, Awhadi S, EnjiliJ, Hosseini S.M, Eslamian S, Ostad-Ali-Askari K. 2017, Optimizing Absorbent Bentonite and Evaluation of Contaminants Removal from Petrochemical Industries Wastewater. International Journal of Constructive Research in Civil Engineering (IJCRCE), 3(2): 34-42. 
[39] [39] Shayannejad M, Eslamian S, Gandomkar A, Marani-Barzani M, Amoushahi-Khouzani M, Majidifar Z, Rajaei-Rizi F, Kazemi M, P. Singh V, Dehghan SH, Shirvani-Dastgerdi H.R, Norouzi H, Ostad-AliAskari K. 2017, A Proper Way to Install Trapezoidal Flumes for Measurements in Furrow Irrigation Systems. International Journal of Research Studies in Agricultural Sciences (IJRSAS), 3(7): 1-5.

[40] DehghanSh, Kamaneh S.A.A., Eslamian S, Gandomkar A, Marani-Barzani M, Amoushahi-Khouzani M, Singh V.P., Ostad-Ali-Askari K. 2017, Changes in Temperature and Precipitation with the Analysis of Geomorphic Basin Chaos in Shiraz, Iran. International Journal of Constructive Research in Civil Engineering (IJCRCE), 3(2): 50-57.

[41] Ostad-Ali-Askari K, Shayannejad M. 2016, FLOOD ROUTING IN RIVERS BY MUSKINGUM'S METHOD WITH NEW ADJUSTED COEFFICIENTS. International Water Technology Journal, IWTJ, 6(3): 189-194.

[42] Ostad-Ali-Askari K, Shayannejad M, Ghorbanizadeh-Kharazi H. 2017, Artificial Neural Network for Modeling Nitrate Pollution of Groundwater in Marginal Area of Zayandeh-rood River, Isfahan, Iran. KSCE Journal of Civil Engineering, 21(1):134-140. Korean Society of Civil Engineers.DOI 10.1007/s12205-016-0572-8.

[43] Soltani A.R, Shayannejad M, Ostad-Ali-Askari K, Ramesh A, Singh V.P., Eslamian S. 2017, Wastewater and Magnetized Wastewater Effects on Soil Erosion in Furrow Irrigation. International Journal of Research Studies in Agricultural Sciences (IJRSAS), 3(8): 1-14. http://dx.doi.org/10.20431/24546224.0308001.

[44] Akhavan S., Abedi-Koupai, J, Mousavi, S, F., Afyuni, M., Eslamian, S. S. and K. C. Abbaspour, 2010, Application of SWAT model to investigate nitrate leaching in Hamadan-Bahar Watershed, Iran, Agriculture, Ecosystems and Environment, Vol. 139, 675-688.

[45] Bazrkar, M. H., Zamani, N., Eslamian, S. S., 2014, Investigation of Landuse Impacts on Sediment Yield using a SWAT (Case Study: Chamgodalan Reservoir Watershed, Iran), Proceeding of 3rdScienceOne International Conference on Environmental Sciences, UAE.

[46] Bazrkar, M.H., Sarang, A. and Eslamian, S.S., 2013, Application of swat for sediment load estimation in Ghamgordlan reservoir watershed, 28-30 March, Perm, Russia.

[47] Fakhri, M., Eslamian, S. S., Rostamian, R., and Fazeli, I, 2012, A Review on Erosion and Sediment Transfer Models with Emphasis on Sediment Modeling of Beheshtabad Sub-basin, North Karoon, using SWAT Model, Ninth International Conference on River Engineering, Ahvaz.

[48] Akhavan, S., Abedi-Koupai, J., Mousavi, S. F., Abbaspour, K., Afyuni, M. and S. S. Eslamian, 2010, Estimation of Blue Water and Green Water Using SWAT Model in Hamadan-Bahar Watershed, The Journal of Science and Technology of Agriculture and Natural Resources, Water and Soil Science, Vol. 14, No. 53, 9-23.

[49] Shayannejad M, Soltani A.R, Arab M.A, Eslamian S, Amoushahi-Khouzani M, Marani-Barzani M, OstadAli-Askari K. 2017, A Simple Method for Land Grading Computations and its Comparison with Genetic Algorithm (GA) Method. International Journal of Research Studies in Agricultural Sciences (IJRSAS), 3(8): 26-38.

[50] Mohieyimen P, Eslamian S, Ostad-Ali-Askari K, Soltani M. 2017, Climate Variability: Integration of Renewable Energy into Present and Future Energy Systems in Designing Residential Buildings. International journal of Rural Development, Environment and Health Research(IJREH), 1(2): 18-30.

[51] Eslamian, S. and F. Eslamian, 2017, Handbook of Drought and Water Scarcity, Vol. 1: Principles of Drought and Water Scarcity, Francis and Taylor, CRC Group, USA, 660 Pages.

[52] Eslamian, S. and F. Eslamian, 2017, Handbook of Drought and Water Scarcity, Vol. 2: Environmental Impacts and Analysis of Drought and Water Scarcity, Francis and Taylor, CRC Group, USA, 680 Pages.

[53] Eslamian, S. and F. Eslamian, 2017, Handbook of Drought and Water Scarcity, Vol. 3: Management of Drought and Water Scarcity, Francis and Taylor, CRC Group, USA, 645. Pages.

[54] Angelakis, A. N., Chiotis, E., Eslamian, S., Weingartner, H., 2017, Underground Aqueducts Handbook, Taylor and Francis Group, CRC Press, USA, 511 Pages.

[55] Zalewski, M., McClain, M. E., and Eslamian, S., 2016, New Challenges and Dimensions of Ecohydrology, Part II Ecohydrology and Hydrobiology, Special Issue, Volume 16, Issue 2, Pages 71-124, Elsevier.

[56] Zalewski, M., McClain, M. E., and Eslamian, S., 2016, New Challenges and Dimensions of Ecohydrology, Part I, Ecohydrology and Hydrobiology, Special Issue, Volume 16, Issue 1, Pages 1-70, Elsevier.

[57] Godarzi, A., Eslamian, S., Ostad-Ali-Askari, K., 2016, Water in Literature Aspects: Social and Cultural Aspects, Nashreshahr, 135 Pages. 
[58] Eslamian, S., Ostad-Ali-Askari, K., Salehi, M., Agha-Esmaeli, M., Sadeghi, M., Navabpour, B., MohriEsfahani, E., Mousavi-Madani, M., Zad-Bagher-Seighalani, E., Sadri, A., Shirvani-Dastgerdi, H. R., 2016, Engineering Operations Research: Linear Planning, Optimization and Genetic Algorithm, Kankash, 126 Pages.

[59] Eslamian, S., Ostad-Ali-Askari, K., Shayannejad, M., Ghasemi-Zeniani, M., Marzi-Nohadani, M., Heidari, F., Mohri-Esfahani, E., Haeri-Hamadani, M., 2016., Groundwater Hydrodynamic, Horoufchin, 193 Pages.

[60] Ostad-Ali-Askari, K., Shayannejad, M., Eslamian, S., Jahangiri, A. A., Shabani, A. H., 2016, Environmental Hydraulics of Open Channel Flows, Kankash, 332 Pages.

[61] Eslamian, S. S. and R. Mirabbasi, 2017, Application of Statistical Methods in Water Sciences, Aeij Publishing, Tehran, Iran, Under Press.

[62] Eslamian, S, 2015, (ed.) Urban Water Reuse Handbook, Francis and Taylor, CRC Group, USA, 1141 Pages.

[63] Eslamian, S., 2014, (ed.) Handbook of Engineering Hydrology, Vol. 1: Fundamentals and Applications, Taylor and Francis, CRC Group, USA, 636 Pages.

[64] Eslamian, S., 2014, (ed.) Handbook of Engineering Hydrology, Vol. 2: Modeling, Climate Change and Variability, Taylor and Francis, CRC Group, USA, 646 Pages.

[65] Eslamian, S., 2014, (ed.) Handbook of Engineering Hydrology, Vol. 3: Environmental Hydrology and Water Management, Taylor and Francis, CRC Group, USA, 606 Pages.

[66] Eslamian, S. S., 2013, Groundwater and Surface Water Interaction (GSWI): 3: Unconvenntional Groundwater, International Journal of Water, Special Issue Volume, Indersciences, Vol. 7, No. 1/2, 1-141.

[67] Eslamian, S. S., 2011, Groundwater and Surface Water Interaction (GSWI): 2. Case Studies, International Journal of Water, Special Issue Volume, Indersciences, Vol. 6, No. 1, 1-136.

[68] Eslamian, S. S., and S. TarkeshEsfahani, 2011, Water Reuse (Urban Waste Water Application), ArkanDanesh Publishing, Isfahan, Iran, 327 Pages.

[69] Sharifani, M. M. and S. S. Eslamian, 2010, Humid Region Fruit Trees, Aeij Publishing, Tehran, Iran.

[70] Eslamian, S. S., 2009, Basin Ecology and Environment (BEE), International Journal of Ecological Economic \& Statistics, Ed., Special Issue Volume, CESER, Vol. 13, No. W09, 1-99.

[71] Eslamian, S. S., 2009, Groundwater and Surface Water Interaction (GSWI): 1. Quality, International Journal of Water, Special Issue Volume, Indersciences, Vol. 5, No. 2, 81-204.

[72] Eslamian, S. S., 2009, Wind Modeling and Frequency Analysis (WMFA), International Journal of Global Energy Issues, Special Issue Volume, Indersciences. Vol. 32, No. 3, 175-304.

[73] Eslamian, S. S., 2008, Stream Ecology and Low Flows (SELF), International Journal of Ecological Economic \& Statistics, Ed., Special Issue Volume, CESER, Vol. 12, No. F08, 1-97.

[74] Eslamian, S. S., Soltani S. and A. Zarei, 2005, Application of Statistical Methods in Environmental Sciences, Arkan Publishing, Isfahan, Iran, 408 p.

[75] Eslamian, S. S. and S. Soltani, 2002, Flood Frequency Analysis, Arkan Publishing, Isfahan, Iran, 332 p.

[76] Eslamian, S. S., 1995, Regional Flood Frequency Analysis Using a New Region of Influence Approach, Ph.D. Thesis, Univ. of New South Wales, School of Civil Engineering, Dept. of Water Engineering, Sydney, NSW, Australia, 1995, Supervised by: Professor David H. Pilgrim, 380 P.

[77] Coles, N. A. and Eslamian, S., 2017, Definition of Drought, Ch. 1 in Handbook of Drought and Water Scarcity, Vol. 1: Principles of Drought and Water Scarcity, Ed. by Eslamian S. and Eslamian F., Francis and Taylor, CRC Press, USA, 1-12.

[78] Dalezios, N. R., Dunkel, Z., Eslamian, S., 2017, Meteorological Drought Indices: Definitions, Ch. 3 in Handbook of Drought and Water Scarcity, Vol. 1: Principles of Drought and Water Scarcity, Ed. by Eslamian S. and Eslamian F., Francis and Taylor, CRC Press, USA, 24-44.

[79] Goyal, M. K. Gupta, V., Eslamian, S., 2017, Hydrological Drought: Water Surface and Duration Curve Indices, Ch. 4 in Handbook of Drought and Water Scarcity, Vol. 1: Principles of Drought and Water Scarcity, Ed. by Eslamian S. and Eslamian F., Francis and Taylor, CRC Press, USA, 45-72.

[80] Dalezios, N. R., Gobin, A., Tarquis Alfonso, A. M., and Eslamian, S., 2017, Agricultural Drought Indices: Combining Crop, Climate, and Soil Factors, Ch. 5 in Handbook of Drought and Water Scarcity, Vol. 1: Principles of Drought and Water Scarcity, Ed. by Eslamian S. and Eslamian F., Francis and Taylor, CRC Press, USA, 73-90. 
[81] TishehZan, P. and Eslamian, S., 2017, Agricultural Drought: Organizational Perspectives, Ch. 6 in Handbook of Drought and Water Scarcity, Vol. 1: Principles of Drought and Water Scarcity, Ed. by Eslamian S. and Eslamian F., Francis and Taylor, CRC Press, USA, 91-108.

[82] Bazrkar, M. H., Eslamian, S., 2017, Ocean Oscillation and Drought Indices: Application, Ch. 8 in Handbook of Drought and Water Scarcity, Vol. 1: Principles of Drought and Water Scarcity, Ed. by Eslamian S. and Eslamian F., Francis and Taylor, CRC Press, USA, 127-136.

[83] Basu, R., Singh, C. K., Eslamian, S., 2017, Cause and Occurrence of Drought, Ch. 9 in Handbook of Drought and Water Scarcity, Vol. 1: Principles of Drought and Water Scarcity, Ed. by Eslamian S. and Eslamian F., Francis and Taylor, CRC Press, USA, 137-148.

[84] Bazrafshan, J., Hejabi, S., Eslamian, S., 2017, Drought Modeling Examples, Ch. 11 in Handbook of Drought and Water Scarcity, Vol. 1: Principles of Drought and Water Scarcity, Ed. by Eslamian S. and Eslamian F., Francis and Taylor, CRC Press, USA, 167-188.

[85] Jonathan Peter Cox, Sara ShaeriKarimi, Eslamian, S., 2017, Real-Time Drought Management, Ch. 13 in Handbook of Drought and Water Scarcity, Vol. 1: Principles of Drought and Water Scarcity, Ed. by Eslamian S. and Eslamian F., Francis and Taylor, CRC Press, USA, 209-216.

[86] Garg, V. and Eslamian, S., 2017, Monitoring, Assessment, and Forecasting of Drought Using Remote Sensing and the Geographical Information System. Ch. 14 in Handbook of Drought and Water Scarcity, Vol. 1: Principles of Drought and Water Scarcity, Ed. by Eslamian S. and Eslamian F., Francis and Taylor, CRC Press, USA, 217-252.

[87] Dalezios, N. R., Tarquis Alfonso, A. M., and Eslamian, S., 2017, Drought Assessment and Risk Analysis, Ch. 18 in Handbook of Drought and Water Scarcity, Vol. 1: Principles of Drought and Water Scarcity, Ed. by Eslamian S. and Eslamian F., Francis and Taylor, CRC Press, USA, 323-344.

[88] Dalezios, N. R., Spyropoulosand, N. V., Eslamian, S., 2017, Remote Sensing in Drought Quantification and Assessment, Ch. 21 in Handbook of Drought and Water Scarcity, Vol. 1: Principles of Drought and Water Scarcity, Ed. by Eslamian S. and Eslamian F., Francis and Taylor, CRC Press, USA, 377-396.

[89] Araghinejad, S., Hosseini-Moghari, S. M., Eslamian, S., 2017, Application of Data-Driven Models in Drought Forecasting, Ch. 23 in Handbook of Drought and Water Scarcity, Vol. 1: Principles of Drought and Water Scarcity, Ed. by Eslamian S. and Eslamian F., Francis and Taylor, CRC Press, USA, 423-440.

[90] Vafakhah, M., and Eslamian, S., 2017, Application of Intelligent Technology in Rainfall Analysis, Ch. 24 in Handbook of Drought and Water Scarcity, Vol. 1: Principles of Drought and Water Scarcity, Ed. by Eslamian S. and Eslamian F., Francis and Taylor, CRC Press, USA, 441-460.

[91] Vafakhah, M., AkbariMajdar, H. and Eslamian, S., 2017, Rainfall Prediction Using Time Series Analysis, Ch. 28 in Handbook of Drought and Water Scarcity, Vol. 1: Principles of Drought and Water Scarcity, Ed. by Eslamian S. and Eslamian F., Francis and Taylor, CRC Press, USA, 517-540.

[92] González, M. H., Garbarini, E. M., Rolla, A. L., and Eslamian, S., 2017, Meteorological Drought Indices: Rainfall Prediction in Argentina, Ch. 29 in Handbook of Drought and Water Scarcity, Vol. 1: Principles of Drought and Water Scarcity, Ed. by Eslamian S. and Eslamian F., Francis and Taylor, CRC Press, USA, 541-570.

[93] Hadizadeh, R. and Eslamian, S., 2017, Modeling Hydrological Process by ARIMA-GARCH Time Series, Ch. 30 in Handbook of Drought and Water Scarcity, Vol. 1: Principles of Drought and Water Scarcity, Ed. by Eslamian S. and Eslamian F., Francis and Taylor, CRC Press, USA, 571-590.

[94] Mujere, N., Yang, X. and Eslamian, S., 2017, Gradation of Drought-Prone Area, Ch. 31 in Handbook of Drought and Water Scarcity, Vol. 1: Principles of Drought and Water Scarcity, Ed. by Eslamian S. and Eslamian F., Francis and Taylor, CRC Press, USA, 591-606.

[95] MahmudulHaque, M., Amir Ahmed, A., Rahman, A., Eslamian, S., 2017, Drought Losses to Local Economy, Ch. 33 in Handbook of Drought and Water Scarcity, Vol. 1: Principles of Drought and Water Scarcity, Ed. by Eslamian S. and Eslamian F., Francis and Taylor, CRC Press, USA, 627-642.

[96] Fakhruddin, B. S. H. M., Eslamian, S., 2017, Analysis of Drought Factors Affecting the Economy, Ch. 34 in Handbook of Drought and Water Scarcity, Vol. 1: Principles of Drought and Water Scarcity, Ed. by Eslamian S. and Eslamian F., Francis and Taylor, CRC Press, USA, 643-656.

[97] Dalezios, N. R., Eslamian, S., 2017, Environmental Impacts of Drought on Desertification Classification, Ch. 3 in Handbook of Drought and Water Scarcity, Vol. 2: Environmental Impacts and Analysis of Drought and Water Scarcity, Ed. by Eslamian S. and Eslamian F., Francis and Taylor, CRC Press, USA, 45-64.

[98] Nazif, S. and Tavakolifar, H., Eslamian, S., 2017, Climate Change Impact on Urban Water Deficit, Ch. 5 in Handbook of Drought and Water Scarcity, Vol. 2: Environmental Impacts and Analysis of Drought and Water Scarcity, Ed. by Eslamian S. and Eslamian F., Francis and Taylor, CRC Press, USA, 81-106. 
[99] Shahid, S., Alamgir, M., Wang, X.-J., Eslamian, S., 2017, Climate Change Impacts on and Adaptation to Groundwater, Ch. 6 in Handbook of Drought and Water Scarcity, Vol. 2: Environmental Impacts and Analysis of Drought and Water Scarcity, Ed. by Eslamian S. and Eslamian F., Francis and Taylor, CRC Press, USA, 107-124.

[100]Orimoogunje, O. O. I., Eslamian, S., 2017, Minimizing the Impacts of Drought, Ch. 8 in Handbook of Drought and Water Scarcity, Vol. 2: Environmental Impacts and Analysis of Drought and Water Scarcity, Ed. by Eslamian S. and Eslamian F., Francis and Taylor, CRC Press, USA, 143-162.

[101]Maleksaeidi, H., Keshavarz, M., Karami, E., Eslamian, S., 2017, Climate Change and Drought: Building Resilience for an Unpredictable Future, Ch. 9 in Handbook of Drought and Water Scarcity, Vol. 2: Environmental Impacts and Analysis of Drought and Water Scarcity, Ed. by Eslamian S. and Eslamian F., Francis and Taylor, CRC Press, USA, 163-186.

[102]Reyhani, M. N., Eslamian, S., Davari, A., 2017, Sustainable Agriculture: Building Social-Ecological Resilience, Ch. 10 in Handbook of Drought and Water Scarcity, Vol. 2: Environmental Impacts and Analysis of Drought and Water Scarcity, Ed. by Eslamian S. and Eslamian F., Francis and Taylor, CRC Press, USA, $187-204$.

[103]Crusberg, T. C., Eslamian, S., 2017, Drought and Water Quality, Ch. 11 in Handbook of Drought and Water Scarcity, Vol. 2: Environmental Impacts and Analysis of Drought and Water Scarcity, Ed. by Eslamian S. and Eslamian F., Francis and Taylor, CRC Press, USA, 205-218.

[104]Gaaloul, N., Eslamian, S., and Laignel, B., 2017, Contamination of Groundwater in Arid and Semiarid Lands, Ch. 16 in Handbook of Drought and Water Scarcity, Vol. 2: Environmental Impacts and Analysis of Drought and Water Scarcity, Ed. by Eslamian S. and Eslamian F., Francis and Taylor, CRC Press, USA, 291-314.

[105]Banjoko, B., Eslamian, S., 2017, Sanitation in Drought, Ch. 17 in Handbook of Drought and Water Scarcity, Vol. 2: Environmental Impacts and Analysis of Drought and Water Scarcity, Ed. by Eslamian S. and Eslamian F., Francis and Taylor, CRC Press, USA, 315-330.

[106]Davari, A., Bagheri, A., Reyhani, M. N., Eslamian, S., 2017, Environmental Flows Assessment in Scarce Water Resources, Ch. 18 in Handbook of Drought and Water Scarcity, Vol. 2: Environmental Impacts and Analysis of Drought and Water Scarcity, Ed. by Eslamian S. and Eslamian F., Francis and Taylor, CRC Press, USA, 331-352.

[107]Qian, Q., Eslamian, S., 2017, Streamflow Quality in Low-Flow Conditions, Ch. 20 in Handbook of Drought and Water Scarcity, Vol. 2: Environmental Impacts and Analysis of Drought and Water Scarcity, Ed. by Eslamian S. and Eslamian F., Francis and Taylor, CRC Press, USA, 375-386.

[108]MohammadzadeMiyab, N., Eslamian, S., Dalezios, N. R., 2017, River Sediment in Low Flow Condition, Ch. 21 in Handbook of Drought and Water Scarcity, Vol. 2: Environmental Impacts and Analysis of Drought and Water Scarcity, Ed. by Eslamian S. and Eslamian F., Francis and Taylor, CRC Press, USA, 387-408.

[109]Pérez-Blanco, C. D., Delacámara., G., Gómez., C. M., Eslamian, S., 2017, Crop Insurance in Drought Conditions, Ch. 23 in Handbook of Drought and Water Scarcity, Vol. 2: Environmental Impacts and Analysis of Drought and Water Scarcity, Ed. by Eslamian S. and Eslamian F., Francis and Taylor, CRC Press, USA, 423-444.

[110]Kahrizi, D., Esfahani, K., Ashraf Mehrabi, A., Ghaheri, M., Azizi Aram, Z., Khosravi, S., Eslamian, S., 2017, Biotechnology for Drought Improvement, Ch. 24 in Handbook of Drought and Water Scarcity, Vol. 2: Environmental Impacts and Analysis of Drought and Water Scarcity, Ed. by Eslamian S. and Eslamian F., Francis and Taylor, CRC Press, USA, 445-460.

[111]Wade, P., Eslamian, S., 2017, Water Issues from a System Dynamics Perspective, Ch. 25 in Handbook of Drought and Water Scarcity, Vol. 2: Environmental Impacts and Analysis of Drought and Water Scarcity, Ed. by Eslamian S. and Eslamian F., Francis and Taylor, CRC Press, USA, 461-488.

[112]Rahman, A., Hajani, E., Eslamian, S., 2017, Rainwater Harvesting in Arid Regions of Australia, Ch. 26 in Handbook of Drought and Water Scarcity, Vol. 2: Environmental Impacts and Analysis of Drought and Water Scarcity, Ed. by Eslamian S. and Eslamian F., Francis and Taylor, CRC Press, USA, 489-500.

[113]Mukherjee, S., Yadav, K., Eslamian, S., 2017, Soil Contaminations in Arid and Semiarid Land, Ch. 29 in Handbook of Drought and Water Scarcity, Vol. 2: Environmental Impacts and Analysis of Drought and Water Scarcity, Ed. by Eslamian S. and Eslamian F., Francis and Taylor, CRC Press, USA, 547-556.

[114]Dayani, S., Sabzalian, M. R., Hadipour, M. Eslamian, S., 2017, Water Scarcity and Sustainable Urban Green Landscape, Ch. 30 in Handbook of Drought and Water Scarcity, Vol. 2: Environmental Impacts and Analysis of Drought and Water Scarcity, Ed. by Eslamian S. and Eslamian F., Francis and Taylor, CRC Press, USA, 557-604. 
[115]Gohari, A., Zareian, M. J., Eslamian, S., Nazari, R. 2017, Interbasin Transfers of Water: Zayandeh-Rud River Basin, Ch. 32 in Handbook of Drought and Water Scarcity, Vol. 2: Environmental Impacts and Analysis of Drought and Water Scarcity, Ed. by Eslamian S. and Eslamian F., Francis and Taylor, CRC Press, USA, 619-630.

[116]Banjoko, B., Eslamian, S., 2017, Environmental Evaluation: Lessons Learned from Case Studies, Ch. 33 in Handbook of Drought and Water Scarcity, Vol. 2: Environmental Impacts and Analysis of Drought and Water Scarcity, Ed. by Eslamian S. and Eslamian F., Francis and Taylor, CRC Press, USA, 631-664.

[117]Abbasova, D., Eslamian, S., Nazari, R., 2017, Paleo-Drought: Measurements and Analysis, Ch. 34 in Handbook of Drought and Water Scarcity, Vol. 2: Environmental Impacts and Analysis of Drought and Water Scarcity, Ed. by Eslamian S. and Eslamian F., Francis and Taylor, CRC Press, USA, 665-674.

[118]Yihdego, Y., Eslamian, S., 2017, Drought Management: Initiatives and Objectives, Ch. 1 in Handbook of Drought and Water Scarcity, Vol. 3: Management of Drought and Water Scarcity, Ed. by Eslamian S. and Eslamian F., Francis and Taylor, CRC Press, USA, 1-26.

[119]Tuncok, I. K., Eslamian, S., 2017, Drought Management Strategies in Water-Stressed/Water-Scarce Regions, Ch. 5 in Handbook of Drought and Water Scarcity, Vol. 3: Management of Drought and Water Scarcity, Ed. by Eslamian S. and Eslamian F., Francis and Taylor, CRC Press, USA, 97-154.

[120]Reinstädtler, S., Islam, S. N., Eslamian, S., 2017, Drought Management for Landscape and Rural Security, Ch. 8 in Handbook of Drought and Water Scarcity, Vol. 3: Management of Drought and Water Scarcity, Ed. by Eslamian S. and Eslamian F., Francis and Taylor, CRC Press, USA, 195-234.

[121]Dalezios, N. R., Eslamian, S., 2017, Drought Assessment and Management for Heat Waves Monitoring, Ch. 9 in Handbook of Drought and Water Scarcity, Vol. 3: Management of Drought and Water Scarcity, Ed. by Eslamian S. and Eslamian F., Francis and Taylor, CRC Press, USA, 235-260.

[122]Kruse, E., Eslamian, S., 2017, Groundwater Management in Drought Conditions, Ch. 11 in Handbook of Drought and Water Scarcity, Vol. 3: Management of Drought and Water Scarcity, Ed. by Eslamian S. and Eslamian F., Francis and Taylor, CRC Press, USA, 275-282.

[123]Araghinejad, S., Hosseini-Moghari, S.-M., Eslamian, S., 2017, Reservoir Operation during Drought, Ch. 12 in Handbook of Drought and Water Scarcity, Vol. 3: Management of Drought and Water Scarcity, Ed. by Eslamian S. and Eslamian F., Francis and Taylor, CRC Press, USA, 283-292.

[124]Eslamian, S., Khosravi, B., Sayahi, M., Haeri-Hamedani, M. 2017, Crises Management Planning and Drought Management Plans, Ch. 13 in Handbook of Drought and Water Scarcity, Vol. 3: Management of Drought and Water Scarcity, Ed. by Eslamian S. and Eslamian F., Francis and Taylor, CRC Press, USA, 293-304.

[125]Halbac-Cotoara-Zamfir, R., Eslamian, S., 2017, Functional Analysis of Regional Drought Management, Ch. 14 in Handbook of Drought and Water Scarcity, Vol. 3: Management of Drought and Water Scarcity, Ed. by Eslamian S. and Eslamian F., Francis and Taylor, CRC Press, USA, 305-328.

[126]Zahraei, A., Saadati, S., Eslamian, S., 2017, Irrigation Deficit: Farmlands, Ch. 16 in Handbook of Drought and Water Scarcity, Vol. 3: Management of Drought and Water Scarcity, Ed. by Eslamian S. and Eslamian F., Francis and Taylor, CRC Press, USA, 343-358.

[127]Amiri, M. J., Eslamian, S., Bahrami, M., Yousefi, N. 2017, Deficit Irrigation: Greenhouse, Ch. 17 in Handbook of Drought and Water Scarcity, Vol. 3: Management of Drought and Water Scarcity, Ed. by Eslamian S. and Eslamian F., Francis and Taylor, CRC Press, USA, 359-372.

[128]Ostad-Ali-Askari, K., Shayanejad, M., Eslamian, S., Zamani, F., Shojaei, N., Navabpour, B., Majidifard, Z., Sadri, A., Ghasemi-Siani, Z., Nourozi, H., Vafaei, O., Homayouni. S.-M.-A., 2017, Deficit Irrigation: Optimization Models, Ch. 18 in Handbook of Drought and Water Scarcity, Vol. 3: Management of Drought and Water Scarcity, Ed. by Eslamian S. and Eslamian F., Francis and Taylor, CRC Press, USA, 373-390.

[129]Eludoyin, A. O., Eludoyin, O. M., Eslamian, S., 2017, Drought Mitigation Practices, Ch. 19 in Handbook of Drought and Water Scarcity, Vol. 3: Management of Drought and Water Scarcity, Ed. by Eslamian S. and Eslamian F., Francis and Taylor, CRC Press, USA, 391-402

[130]Irshad, S. M., Eslamian, S., 2017, Politics of Drought Management and Water Control in India, Ch. 22 in Handbook of Drought and Water Scarcity, Vol. 3: Management of Drought and Water Scarcity, Ed. by Eslamian S. and Eslamian F., Francis and Taylor, CRC Press, USA, 447-460.

[131]Pati, R., Eslamian, S., 2017, Drought Management for Horticultural Crops in India, Ch. 23 in Handbook of Drought and Water Scarcity, Vol. 3: Management of Drought and Water Scarcity, Ed. by Eslamian S. and Eslamian F., Francis and Taylor, CRC Press, USA, 461-482.

[132]Khan, S., Eslamian, S., 2017, , Ch. 25 in Handbook of Drought and Water Scarcity, Vol. 3: Management of Drought and Water Scarcity, Ed. by Eslamian S. and Eslamian F., Francis and Taylor, CRC Press, USA, 495-526. 
[133]Sedaei, L., Sedaei, N., Cox, J. P., Dalezios N. R., Eslamian, S., 2017, Forest Fire Mitigation under Water Shortage, Ch. 26 in Handbook of Drought and Water Scarcity, Vol. 3: Management of Drought and Water Scarcity, Ed. by Eslamian S. and Eslamian F., Francis and Taylor, CRC Press, USA, 527-550.

[134]TorabiFarsani, N., Neto de Carvalho, C., Eslamian, S., 2017, Education Program for Drought, Ch. 27 in Handbook of Drought and Water Scarcity, Vol. 3: Management of Drought and Water Scarcity, Ed. by Eslamian S. and Eslamian F., Francis and Taylor, CRC Press, USA, 551-566.

[135]Nazif, S. and Tavakolifar, H., Eslamian, S., 2017, Emergency Drought Consequence Plan, Ch. 30 in Handbook of Drought and Water Scarcity, Vol. 3: Management of Drought and Water Scarcity, Ed. by Eslamian S. and Eslamian F., Francis and Taylor, CRC Press, USA, 640-658

[136]MohseniSaravi, M., Shabazi, R., Eslamian, S., 2017, Coping With Drought- Ch. 31 in Handbook of Drought and Water Scarcity, Vol. 3: Management of Drought and Water Scarcity, Ed. by Eslamian S. and Eslamian F., Francis and Taylor, CRC Press, USA, 659-673

[137]Eslamian, S., Mohri-Isfahani, E., Mahdavi, A., Rajaei-Rizi, F., Marzi-Nouhedani, M., Ghasemi-Zanyani, M., Dehghani, S., Hosseini-Teshnizi., S. Z., Esmaeili, F. , Shojaei, N., Ghane, M., Hasantabar-Amiri, A., 2017, Integrated Water Resources Management Under Water Scarcity, Ch. 32 in Handbook of Drought and Water Scarcity, Vol. 3: Management of Drought and Water Scarcity, Ed. by Eslamian S. and Eslamian F., Francis and Taylor, CRC Press, USA, 675-695.

[138]Aghaei, A., Eslamian, S., Dalezios, N. R., Saeidi-Rizi, A., Bahrebardar, S., 2017, Drought and Dust Management, Ch. 33 in Handbook of Drought and Water Scarcity, Vol. 3: Management of Drought and Water Scarcity, Ed. by Eslamian S. and Eslamian F., Francis and Taylor, CRC Press, USA, 696-???.

[139]Eslamian, S., Dalezios, N. R., Singh, V. P., Adamowaski, J., , Mohamadifard, S., Bahmani, R., Eskandari, S., Zomorodian, M., Arefeyan, A., Dehghani, S., Aghaesmaeili, M., Shahbazi, M., Amoushahi, M. T., Yousefi, N., Namdi, A., 2017, Drought Management: Current Challenges and Future Outlook, Ch. 34 in Handbook of Drought and Water Scarcity, Vol. 3: Management of Drought and Water Scarcity, Ed. by Eslamian S. and Eslamian F., Francis and Taylor, CRC Press, USA, ???-???.

[140]Eslamian, S., Davari, A., and Reyhani, M. N., 2017, Iranian Qanāts: An Ancient and Sustainable Water Resources Utilization, Ch. 9, in Underground Aqueducts Handbook, Ed. By Angelakis A. N. et al., Taylor and Francis, CRC Group, 123-150.

[141]Khan, S., and Eslamian , S., 2017, Managing Drought through Qanāt and Water Conservation in Afghanistan, Ch. 22, in Underground Aqueducts Handbook, Ed.By Angelakis A. N. et al., Taylor and Francis, CRC Group, 385-402.

[142]Wessels, J. I., Vardakos, S., Weingartner, H., Eslamian, S., Angelakis, A. N., 2017, Underground Aqueducts: Past, Present, and Future Trends, Ch. 29 in Underground Aqueducts Handbook, Ed. By Angelakis A. N. et al., Taylor and Francis, CRC Group, 491-510.

[143]Dalezios, N.R., Tarquis, A. M. and Eslamian, S. 2017: Droughts. Chapter 5, in book: Environmental Hazards Methodologies for Risk Assessment and Management. Editor: Dalezios, N. R., International Water Association Publishing, London, UK, 177-210.

[144]Dalezios, N. R. and Eslamian, S, 2017, Environmental Hazards Methodologies for Risk Assessment and Management, Ed. By Dalezios, N. R., IWA Publishing,

[145]Bazrkar, M. H., Adamowski, J., Eslamian, S., 2017, Water System Modeling, in Mathematical Advances Towards Sustainable Environmental Systems, Ed. by Furze, J.N., Swing, K., Gupta, A.K., McClatchey, R., Reynolds, D., Springer International Publishing, Switzerland, 61-88.

[146]Zareeian, M.J., Eslamian, S., Gohari, A., and Adamowski, J. 2017. The Effect of Climate Change on Watershed Water Balance, in Mathematical Advances Towards Sustainable Environmental Systems, Ed. by Furze, J.N., Swing, K., Gupta, A.K., McClatchey, R., Reynolds, D., Springer International Publishing, Switzerland, 215-238.

[147]Bazrkar, M. H., Zamani, N., Eslamian, S., Eslamian, A., Dehghan, Z., 2015, Urbanization and Climate Change, Handbook of Climate Change Adaptation, Ed.By Leal Filho, W., Springer, 619-655.

[148]Gohari, A., Zareeian, M. J. and Eslamian, S., 2015, A multi-model framework for climate change impact assessment, Handbook of Climate Change Adaptation, Ed.By Leal Filho, W., Springer, 17-35.

[149]Chen, Z., Ngo, H. H., Guo,W, and Eslamian, S., 2015, Water Shortages, in Urban Water Reuse Handbook, Ch. 1, Ed. By Eslamian, S., Taylor and Francis, CRC Group, USA, 3-14.

[150]Boogaard, F. and Eslamian, S., 2015, Water Reuse and Sustainable Urban Drainage Systems, in Urban Water Reuse Handbook, Ch. 4, Ed. By Eslamian, S., Taylor and Francis, CRC Group, USA, 37-44.

[151]Shah Naqvi, S. A. A., Sultan, A., and Eslamian, S., 2015, Water Quality Issues in Urban Water, in Urban Water Reuse Handbook, Ch. 8, Ed. By Eslamian, S., Taylor and Francis, CRC Group, USA, 99-112. 
[152]Kumar Singh, Ch., Jha, N., and Eslamian, S., 2015, Reuse, Potable Water, and Possibilities, in Urban Water Reuse Handbook, Ch. 9, Ed. By Eslamian, S., Taylor and Francis, CRC Group, USA, 113-126.

[153]Kohansal, M. M., Saadati, S., TarkeshEsfahany, S., and Eslamian, S., 2015, Urban Water Reuse in Industry, in Urban Water Reuse Handbook, Ch. 11, Ed. By Eslamian, S., Taylor and Francis, CRC Group, USA, 137-148.

[154]Kumar, M., Chidambaram, S., Ramanathan, A. L., Goswami, R., and Eslamian, S., 2015, Criterion, Indices, and Classification of Water Quality and Water Reuse Options, Urban Water Reuse Handbook, Ch. 13, Ed. By Eslamian, S., Taylor and Francis, CRC Group, USA, 163-176.

[155]Eslamian, F., Eslamian, S., and Eslamian, A., 2015, Water Reuse Guidelines for Agriculture, Urban Water Reuse Handbook, Ch. 14, Ed. By Eslamian, S., Taylor and Francis, CRC Group, USA, 177-186.

[156]Eslamian, A., Eslamian, F., and Eslamian, S., 2015, Water Reuse Guidelines for Industry, Urban Water Reuse Handbook, Ch. 15, Ed. By Eslamian, S., Taylor and Francis, CRC Group, USA, 187-194.

[157]Eslamian, S., Eslamian, F., and Eslamian, A., 2015, Water Reuse Guidelines for Recreation, Urban Water Reuse Handbook, Ch. 16, Ed. By Eslamian, S., Taylor and Francis, CRC Group, USA, 195-200.

[158]Banjoko, B. and Eslamian, S., 2015, Environmental Impact Assessment: An Application to Urban Water Reuse, Urban Water Reuse Handbook, Ch. 20, Ed. By Eslamian, S., Taylor and Francis, CRC Group, USA, 229-242.

[159]Amiri, M. J., Eslamian, S., Arshadi, M., and Khozaei, M., 2015, Water Recycling and Community, Urban Water Reuse Handbook, Ch. 22, Ed. By Eslamian, S., Taylor and Francis, CRC Group, USA, 261-274.

[160]Ferdaush, J., Noor Islam, Sh., Reinstädtler, S., and Eslamian, S., 2015, Ethical and Cultural Dimension of Water Reuse, Urban Water Reuse Handbook, Ch. 24, Ed. By Eslamian, S., Taylor and Francis, CRC Group, 285-296.

[161]Bazrkar, M. H., Zamani, N., and Eslamian, S., 2015, Evaluation of Socioeconomic Impacts of Urban Water Reuse Using System Dynamics Approach, Urban Water Reuse Handbook, Ch. 28, Ed. By Eslamian, S., Taylor and Francis, CRC Group, 331-340.

[162]Mujere, N. and Eslamian, S., 2015, Blackwater System, Urban Water Reuse Handbook, Ch. 33, Ed. By Eslamian, S., Taylor and Francis, CRC Group, 393-404.

[163]Abu-Ghunmi, L., and Eslamian, S., 2015, Graywater, Urban Water Reuse Handbook, Ch. 34, Ed. By Eslamian, S., Taylor and Francis, CRC Group, 405-420.

[164]Eslamian, S., Amininezhad, S. M., and Amininejad, S. M., 2015, Contamination Warning System, Urban Water Reuse Handbook, Ch. 39, Ed. By Eslamian, S., Taylor and Francis, CRC Group, 481-488.

[165]Crusberg, T. C., and Eslamian, S., 2015, Choosing Indicators of Fecal Pollution for Wastewater Reuse Opportunities, Urban Water Reuse Handbook, Ch. 42, Ed. By Eslamian, S., Taylor and Francis, CRC Group, 511-520.

[166]Boogaard, F. and Eslamian, S , 2015, Wastewater Monitoring, Urban Water Reuse Handbook, Ch. 48, Ed. By Eslamian, S., Taylor and Francis, CRC Group, 583-586.

[167]Mujere, N., and Eslamian, S., 2015, Urban Wetland Hydrology and Water Purification, Urban Water Reuse Handbook, Ch. 50, Ed. By Eslamian, S., Taylor and Francis, CRC Group, 603-616.

[168]Nazif, S., and Eslamian , S., 2015, Urban Wetland Hydrology and Changes , Urban Water Reuse Handbook, Ch. 51, Ed. By Eslamian, S., Taylor and Francis, CRC Group, 617-640.

[169]Banjoko, B., and Eslamian, S., 2015, Phytoremediation, Urban Water Reuse Handbook, Ch. 53, Ed. By Eslamian, S., Taylor and Francis, CRC Group, 657-702.

[170]Rivas Hernández, A., Rivas Acosta, I., and Eslamian, S., .2015, Treatment Wetlands: Fundamentals, Urban Water Reuse Handbook, Ch. 54, Ed. By Eslamian, S., Taylor and Francis, CRC Group, 703-716.

[171]Rahman, A., and Eslamian, S., 2015, Rainwater Tanks as a Means of Water Reuse and Conservation in Urban Areas, Urban Water Reuse Handbook, Ch. 60, Ed. By Eslamian, S., Taylor and Francis, CRC Group, 797-808.

[172]Qian, Q., and Eslamian, S., 2015, Groundwater Recharge and Unconventional Water: Design and Management Criteria, Urban Water Reuse Handbook, Ch. 61, Ed. By Eslamian, S., Taylor and Francis, CRC Group, 809-816.

[173] Shayannejad M, Arab M.A, Eslamian S, Amoushahi-Khouzani M, Marani-Barzani M, Ostad-Ali-Askari K. 2017, A Simple Method for Land Grading Computations and its Comparison with Genetic Algorithm (GA) Method.

[174]International Journal of Research Studies in Agricultural Sciences (IJRSAS), 3(8): 26-38. 
[175]Mohieyimen P, Eslamian S, Ostad-Ali-Askari K, Soltani M. 2017, Climate Variability: Integration of Renewable Energy into Present and Future Energy Systems in Designing Residential Buildings. International journal of Rural Development, Environment and Health Research(IJREH), 1(2): 18-30.

[176] Shayannejad M, Ostad-Ali-Askari K, Eslamian S, et al. 2017, Flow Hydraulic Investigation of the Wastewater on the Soil and Magnetic Field Effects in This Field. International Journal of Constructive Research in Civil Engineering (IJCRCE), 3(3): 1-15. Shayannejad M, Eslamian S, Singh V.P., Ostad-AliAskari K, et al. 2017, Evaluation of Groundwater Quality for Industrial Using GIS in Mountainous Region of Isfahan Province, Koh-Payeh, Isfahan, Iran. International Journal of Constructive Research in Civil Engineering (IJCRCE), 3(3): 24-37.

[177]Eslamian S, P. Singh V, Ostad-Ali-Askari K, R. Dalezios N, Yihdego Y, et al. 2017, Assessment of Aridity Using Geographical Information System in Zayandeh-Roud Basin, Isfahan, Iran. International Journal of Mining Science (IJMS), 3(2): 49-61.

[178] Askari Z, Samadi-Boroujeni H, Fattahi-Nafchi R, Yousefi N, Eslamian S, Ostad-Ali-Askari K, P. Singh V, R. Dalezios N. 2017, Prediction Comparison of Flow Resistance in Channels with Rounded and Angular Coarse Rough Beds. American Research Journal of Civil And Structural, 3(1): 1-15.

Citation: M. Ghane et al., "Sensitivity Analysis of Runoff Model by SWAT to Meteorological Parameters: A Case Study of Kasillian Watershed, Mazandaran, Iran", International Journal of Research Studies in Agricultural Sciences (IJRSAS), vol. 3, no. 10, p.20, 2017. http://dx.doi.or g/10.20431/2454-6224.0310003

Copyright: () 2017 Authors. This is an open-access article distributed under the terms of the Creative Commons Attribution License, which permits unrestricted use, distribution, and reproduction in any medium, provided the original author and source are credited. 